\title{
Cockle Cerastoderma edule fishery collapse in the Ría de Arousa (Galicia, NW Spain) associated with the protistan parasite Marteilia cochillia
}

\author{
Antonio Villalba ${ }^{1, *}$, David Iglesias ${ }^{1}$, Andrea Ramilo ${ }^{1}$, Susana Darriba ${ }^{2}$, \\ José M. Parada ${ }^{1}$, Edgar No ${ }^{1}$, Elvira Abollo ${ }^{3}$, José Molares ${ }^{1}$, María J. Carballal ${ }^{1}$ \\ ${ }^{1}$ Centro de Investigacións Mariñas (CIMA), Consellería do Medio Rural e do Mar, Xunta de Galicia, \\ 36620 Vilanova de Arousa, Spain \\ ${ }^{2}$ Instituto Tecnolóxico para o Control do Medio Mariño de Galicia (INTECMAR), Consellería do Medio Rural e do Mar, \\ Xunta de Galicia, 36611 Vilagarcía de Arousa, Spain \\ ${ }^{3}$ Centro Tecnológico del Mar - Fundación CETMAR, 36208 Vigo, Spain
}

\begin{abstract}
The highest shellfishery catch in Galicia (NW Spain) has traditionally been cockle Cerastoderma edule. The shellfish bed located in Lombos do Ulla (Ría de Arousa) used to be among those with the highest cockle production; however, cockle mortality rate increased sharply in this bed in April 2012, reaching $100 \%$ in May 2012. Salinity and temperature were discounted as potential causes of the mortality. Marteiliosis, which was first detected in February 2012 and reached $100 \%$ prevalence in April 2012, was identified as the most probable cause. Marteiliosis had never been detected in Galician cockles, but extensive surveillance of the Galician coast in May to July 2012 detected marteiliosis in most cockle beds of the Ría de Arousa, whereas it was not found in other rías; 2 mo later, the cockle catch in the Ría de Arousa became negligible. Examination of the aetiological agent of marteiliosis with light and transmission electron microscopy supported its assignation to the genus Marteilia; morphological features showed similarity, but not complete identity, with the recently described species M. cochillia Carrasco et al., 2013. Regarding its molecular characterisation, a consensus sequence of $4433 \mathrm{bp}$ containing a partial sequence of the intergenic spacer region, the complete 18S rRNA gene and a partial sequence of the first internal transcribed spacer region was obtained. The obtained sequences were compared with those available for Marteilia spp. and other Paramyxida. Molecular data support that this parasite corresponds to the species $M$. cochillia, and a PCR assay was designed for its specific diagnosis. The association of huge cockle mortality with $M$. cochillia infection urges extreme caution to avoid spreading this disease.
\end{abstract}

KEY WORDS: Marteiliosis · Paramyxida $\cdot$ Mollusc $\cdot$ Ultrastructure $\cdot$ SSU rDNA $\cdot$ ITS $\cdot$ IGS Resale or republication not permitted without written consent of the publisher

\section{INTRODUCTION}

The cockle Cerastoderma edule fishery has traditionally been the most important shellfishery in terms of biomass on the Galician (NW Spain) coast. The average annual landing of cockles in this region for the period 2002 to 2011 was $3764 \mathrm{t}$ (official records in www.pescadegalicia.com). The shellfish bed located in Lombos do Ulla, in the Ría de Arousa, used to be among those with the highest cockle catch in Galicia. High cockle mortality in this bed occurred occasionally due to very low salinity associated with heavy rains because of its location in the mouth of the Ulla River, the main tributary of the Ría de Arousa (Parada et al. 2012). Two pathological conditions have been associated with periodic episodes of cockle mortality 
in this bed: one is disseminated neoplasia and the other is characterised by large foci of heavy haemocytic infiltration of connective tissue of various organs (Carballal et al. 2001, Villalba et al. 2001). Nevertheless, high recruitment in the bed allowed the recovery of cockle production after high mortality caused by low salinity or disease outbreaks. Analysis of population dynamics in this cockle bed started in 2002 to assist shellfishery management; the analysis is based on surveys performed twice each year, involving estimation of spatial distribution of cockle density, cockle biomass and size/age structure of the population (Parada et al. 2006, Parada \& Molares 2013). Additionally, a surveillance programme to estimate cockle mortality and to assess the health status through histopathology, based on monthly sampling, started in 2007; the programme also involved monitoring of salinity and temperature. Cockle mass mortality in this bed was reported by shellfishermen in May 2012, which was confirmed within the CIMA surveillance programme. This mass mortality was associated with an outbreak of marteiliosis, a disease that had not been previously detected in Galician cockles.

Marteiliosis is caused by protistan parasites of the genus Marteilia (Grizel et al. 1974). Based on ultrastructural characteristics of specific organelles, this genus was initially thought to be related to haplosporidians (Perkins 1976, 1979); however, this relationship was later rejected (Perkins 1988), giving priority to the multicellularity of the genus Marteilia, and it was placed in the phylum Paramyxea (Desportes \& Perkins 1990). Cavalier-Smith \& Chao (2003) demoted that phylum to the level of order Paramyxida, in the class Ascetosporea, within the phylum Cercozoa. The current taxonomical trend includes the genus Marteilia within the Rhizaria (supergroup), Cercozoa (first rank), Paramyxida (second rank) (Adl et al. 2005). The type species of this genus, $M$. refringens, was blamed for mass mortalities of the European flat oyster Ostrea edulis first in France and later in other European countries (Grizel et al. 1974, Massó 1978, Alderman 1979, van Banning 1979).

Mussels Mytilus edulis and M. galloprovincialis are also susceptible to marteiliosis. Comps et al. (1981) described the species Marteilia maurini infecting mussels in the Italian north Adriatic coast; those authors considered this parasite different from the type species $M$. refringens based on the different host and on ultrastructural characteristics. Nevertheless, the validity of these criteria to differentiate the mussel parasite from $M$. refringens was considered dubious (Villalba et al. 1993a, Longshaw et al. 2001). Molecu- lar analyses also raised doubts about whether the mussel parasite was a different species from $M$. refringens (López-Flores et al. 2004). The occurrence of $M$. refringens in the ovary of the planktonic copepod Paracartia grani led to the hypothesis that the copepod is an intermediate host of the parasite (Audemard et al. 2002). The geographic distribution of $M$. refringens spans from Sweden along to the European coast to Greece, with some areas where the parasite has never been located, including records in northern Africa, namely Morocco and Tunisia (World Organisation for Animal Health 2013). The World Organisation for Animal Health included $M$. refringens on the list of notifiable diseases (www.oie.int/en/animal-health-in-the-world/ oie-listed-diseases-2013/) and on the list of nonexotic diseases requiring surveillance by the European Regulation on Animal Health (Council of the European Union 2006).

Another species of this genus, Marteilia sydneyi, is the aetiological agent of QX disease, responsible for high mortality of the Sidney rock oyster Saccostrea glomerata in Australian waters (Perkins \& Wolf 1976). Two more species were proposed within the genus, $M$. lengehi, detected in the hooded oyster S. cucullata from the Persian Gulf (Comps 1976), and M. christenseni, found in the clam Scrobicularia plana in France (Comps 1983); these 2 species are poorly characterised, especially the former, probably because they were not associated with abnormal mortality. Feist et al. (2009) proposed suppressing the genus Marteilioides and transferring the type species Marteilioides chungmuensis to Marteilia, thus including another species in the genus. M. chungmuensis parasitises ovocytes of the Pacific oyster Crassostrea gigas in Korea (Comps et al. 1986) and Japan (Itoh et al. 2002). A number of mollusc species have been found hosting known Marteilia species or undetermined Marteilia sp. parasites (reviewed by Berthe et al. 2004, Aranguren et al. 2011). Among them, a Marteilia sp. parasite was detected as the possible agent of cockle Cerastoderma edule mortality in the Auray River (Brittany, NW France) (Comps et al. 1975). More recently, marteiliosis associated with cockle mortality in the Delta del'Ebre (Catalonia, NE Spain) was reported (Carrasco et al. 2011); molecular analysis of this parasite revealed differences with the known Marteilia species, thus leading those authors to hypothesise that it was a new species, designating this parasite Marteilia sp. type C (Carrasco et al. 2012). Recent transmission electron microscopy (TEM) characterisation allowed completion of the new species description of M. cochillia (Carrasco et al. 2013). 
In Galicia, Marteilia refringens is endemic and infects mussels Mytilus galloprovincialis (Villalba et al. 1997). Cases of infection with this parasite in flat oysters Ostrea edulis have rarely been detected in this region in the last 30 yr (A. Villalba, S. Darriba and M. J. Carballal pers. obs.) and likely corresponded to infected oysters that had been introduced from other regions. $M$. refringens was also detected in mussels of the non-indigenous invasive species Xenostrobus securis collected in the Ría de Vigo (Pascual et al. 2010). Marteilia sp. parasites have rarely been detected infecting clams Ruditapes decussatus and Tapes rhomboides (Villalba et al. 1993b) and more frequently in razor clams Solen marginatus (López \& Darriba 2006). However, no case of marteiliosis had been observed in cockles before 2012 in Galicia.

Here we report on the marteiliosis outbreak in 2012 in the Ría de Arousa

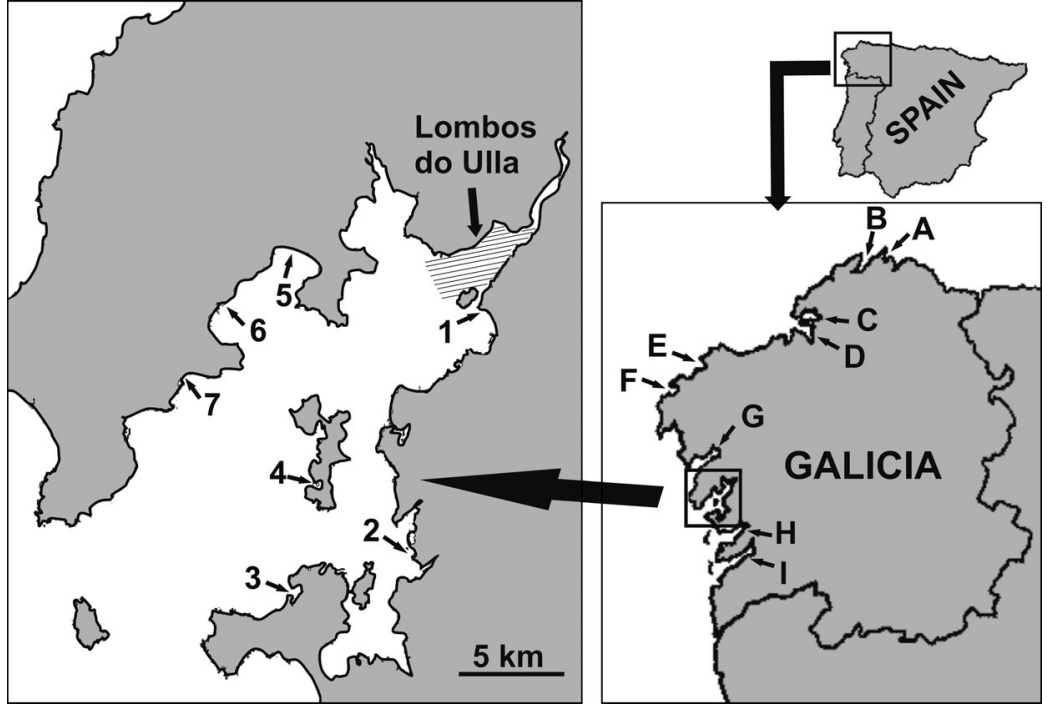

Fig. 1. Ría de Arousa (framed) and map of Galicia (right), Spain, showing the area of the Lombos do Ulla shellfish bed (striped area) in the mouth of the Ulla River (Ría de Arousa) and the location of the other sampling points. Sampled beds in the Ría de Arousa: 1, on-growing plot in Carril; 2, O Sarrido (Cambados); 3, Moreira (O Grove); 4, Aceñas (Illa de Arousa); 5, Barraña (Cabo de Cruz); 6, Raposiños (Pobra do Caramiñal); 7, Cruces (Palmeira). Other sampled rías in Galicia: A, O Barqueiro; B, Ortigueira; C, Ferrol; D, Betanzos; E, Corme-Laxe; F, Camariñas; G, Muros; H, Pontevedra; I, Vigo and discuss the responsibility of marteiliosis for cockle mass mortality, leading to fishery collapse; we also consider the role of environmental conditions (temperature and salinity) and other pathological conditions. The aetiological agent of marteiliosis is characterised based on light and TEM observations, as well as analyses of the sequences of the small subunit ribosomal DNA (SSU rDNA), first internal transcribed spacer (ITS1) and intergenic spacer (IGS) regions, which led us to identify it as M. cochillia.

\section{MATERIALS AND METHODS}

\section{Shellfish bed of Lombos do Ulla}

One of the most productive shellfish beds in Galicia is located in the area named Lombos do Ulla (Parada et al. 2006), in the mouth of the Ulla River $\left(42^{\circ} 38^{\prime} \mathrm{N}\right.$, $8^{\circ} 46^{\prime} \mathrm{W}$ ), which is the main tributary of the Ría de Arousa (Fig. 1). The total bed surface is 1134.7 ha. This bed is shallow (1-5 $\mathrm{m}$ in depth) and mostly subtidal, although a small portion becomes uncovered during spring tides. The highest catch in this location used to correspond to cockles Cerastoderma edule, with an annual average landing of $534 \mathrm{t}$ for the period 2002 to 2011; other catches correspond to 3 clam spe-

cies, viz. Ruditapes philippinarum (75 t), R. decussatus (40 t) and Venerupis corrugata (8 t), all of which are sympatric with cockles (CIMA unpublished). The estuarine character of the area involves wide salinity fluctuation; occasionally, sharp salinity decreases caused by heavy rain leads to high shellfish mortality (Parada et al. 2012).

\section{Estimation of cockle abundance}

A programme to analyse the population dynamics of the exploited shellfish species in Lombos do Ulla started in September 2002 to assist shellfishery management (Parada et al. 2006). The programme involved 2 sampling campaigns each year, one in September and the other in April, before the start and after the end of the fishing season, respectively. Stratified regular sampling was performed to estimate abundance and spatial distribution. Initially, 74 sampling stations were involved, with $275 \mathrm{~m}$ distance between stations; eventually the number of sampling stations increased to 137 . Two samples per station were collected with a Petersen dredge (0.23 $\mathrm{m}^{2}$ sampling surface); the collected materials were sieved through a $5 \mathrm{~mm}$ mesh and stored frozen until they were processed. Each bivalve mol- 
lusc corresponding to a commercial species was counted and measured (anteroposterior length). The estimation of density and biomass was performed with standard statistics for stratified models (Krebs 1998), using the software tool ARouSA (Parada \& Molares 2009).

Additionally, monitoring of newly recruited cockle cohorts started in September 2011. The cohort recruited that year was easily identified in September 2011 (length mode $=18 \mathrm{~mm}$ ). Considering that the minimum market size was $28 \mathrm{~mm}$ in length, the newly recruited cohort could not be fished before the autumn of the next year. Monitoring of the recruited cohort was performed at 1 sampling station with high cockle recruitment (station HD), and involved taking 2 samples and processing them as described above. In the laboratory, the cockles in those samples were measured, and their size (length) structure was analysed to identify and quantify the number of cockles corresponding to the 2011 cohort; the density (ind. $\mathrm{m}^{-2}$ ) corresponding to that cohort was then calculated. In May 2012, a newly recruited cohort (length mode $=10 \mathrm{~mm}$ ) was detected at station HD, and it was monitored as described above. The natural instantaneous mortality rate $(Z)$ corresponding to each cohort was calculated as follows:

$$
Z=-\ln \left(D_{t} / D_{0}\right)
$$

where $D_{t}$ is the density of the cohort recorded on sampling date $(t)$, and $D_{0}$ is the density recorded on the previous sampling date (King 2007). The instantaneous mortality rate was standardised to $30 \mathrm{~d}$ periods and then converted to percentage:

$$
\text { Mortality }(\%)=100(1-\exp [-Z])
$$

\section{Estimation of mortality rate and evaluation of health status}

Surveillance of cockle health status and mortality rate in Lombos de Ulla started in February 2007. Sampling was performed monthly, involving the collection of 105 adult cockles (length $>25 \mathrm{~mm}$ ) from the bed, 30 of which were taken to the laboratory for histological analysis; the remaining 75 cockles were distributed in 5 plastic boxes $(57 \times 36 \times 23 \mathrm{~cm}$, length $\times$ width $\times$ height) at 15 ind. box ${ }^{-1}\left(75\right.$ ind. $\mathrm{m}^{-2}$ ), to estimate mortality rate. The boxes had been filled with sediment from the bed, and after setting the cockles, they were covered with a net to avoid predation and cockle loss; the boxes were then set within a stainless steel frame, which was submerged to the bottom (Fig. 2). After $1 \mathrm{mo}$, coinciding with the next sampling, the frame with the boxes was raised on board, and the live and dead cockles in each box were counted. Live cockles in the boxes were not reused, and the sediment was changed when necessary to prevent anoxia. Mortality rate recorded in each sampling period was standardised to $30 \mathrm{~d}$. In monitoring the 2011- and 2012-recruited cohorts, 30 cockles were taken from the monthly samples of each cohort and processed for histological analysis. Live adult cockles (length $>25 \mathrm{~mm}$ ) as well as cockles recruited in 2011 were not found in the bed from May 2012 onwards,
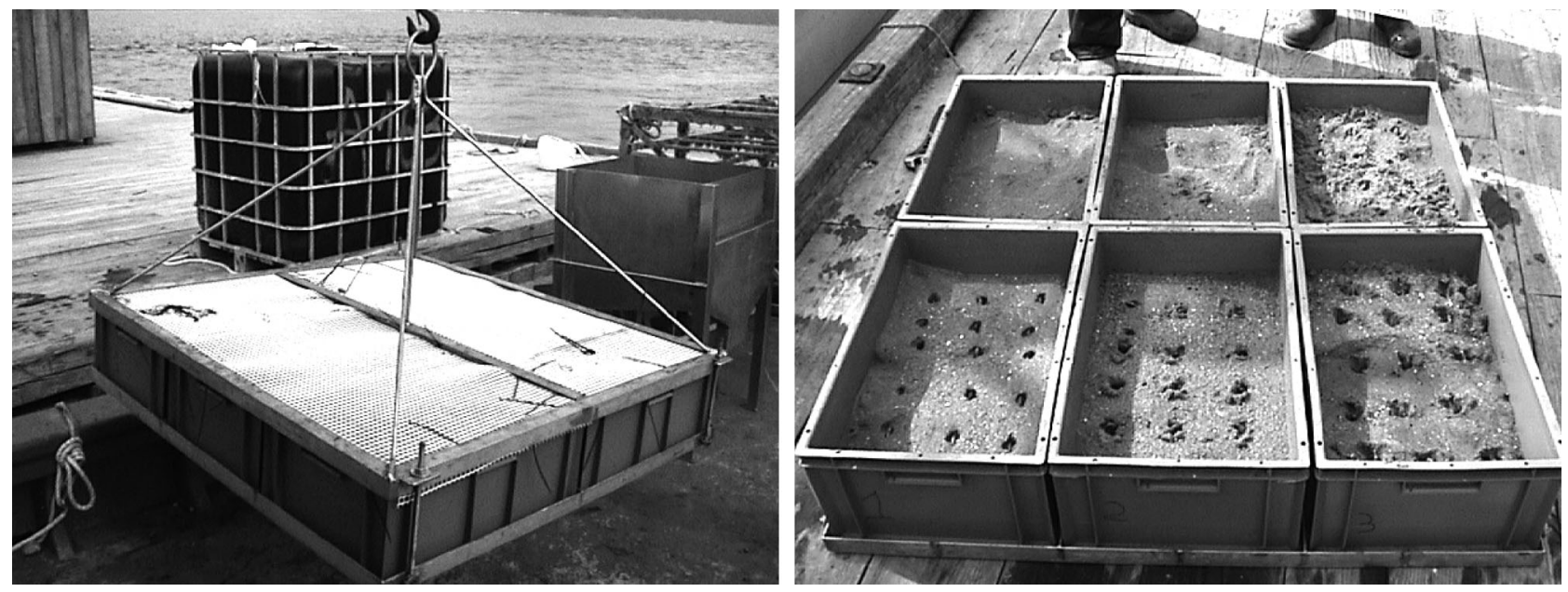

Fig. 2. Cerastoderma edule. Boxes used to estimate cockle mortality in Lombos do Ulla. (Left) Boxes covered with a plastic net within a stainless steel frame in the process of being submersed; (Right) 6 uncovered boxes, filled with sediment, 5 of which hold 15 cockles each 
while cockles recruited in 2012 were not found from September 2012. Thus, the surveillance finished in May 2012 and September 2012, respectively.

\section{Sampling of other mollusc species}

Thirty carpet-shell clams Ruditapes decussatus and 30 Manila clams $R$. philippinarum, all of them market sized (length $>40 \mathrm{~mm}$ ), were collected from Lombos do Ulla in April 2012 and taken to the laboratory to diagnose marteiliosis by histological analysis.

\section{Temperature and salinity records}

Water salinity and temperature were recorded every 10 min with a sensor set in 1 of the boxes used to estimate cockle mortality, beginning in January 2009. The lack of earlier salinity records necessitated an indirect way to estimate salinity values. Thus, a model designed by Parada et al. (2012), integrating other environmental variables with long-term time records (net rainfall in the river basin, wind direction and force, and tidal amplitude), provided the daily mean salinity of the bottom water in the centre of the bed at high tide. The mean monthly temperature and the monthly minimum salinity in the years 2011 and 2012 were compared with those of previous years to determine whether temperature or salinity values recorded in 2011 and 2012 were abnormal and could have caused cockle mass mortality.

\section{Gathering information on cockle beds from other locations}

The list of cockle beds that are sampled annually in May and June within the programme of surveillance of shellfish health along the Galician coast, performed by INTECMAR, was expanded in 2012 due to detection of cockle mass mortality in Lombos do Ulla, with emphasis on the Ría de Arousa. The cockle beds, whose location is shown in Fig. 1, were sampled once between 2 May and 3 July 2012; 30 adult cockles (length $>25 \mathrm{~mm}$ ) were taken from each location and processed for histological analysis. Information on sales corresponding to cockle catch in the whole Ría de Arousa for the period 1997 to 2012 was obtained from the records of the Consellería do Medio Rural e do Mar (Rural and Sea Department of the Galician Government) accessible through www. pescadegalicia.com.

\section{Light microscopy}

Cockles selected for diagnosis were measured (anteroposterior length) and weighed; they were then shucked and a piece ( $5 \mathrm{~mm}$ thick) of tissue including visceral mass, gills, mantle and foot was taken from every cockle. Tissue was fixed in Davidson's solution, embedded in paraffin and sectioned with a rotary microtome, and $5 \mu \mathrm{m}$ thick sections were stained with Harris' haematoxylin and eosin. Additionally, for cockles from beds other than Lombos do Ulla, a piece of digestive gland was taken and used to produce imprints on a slide, which were fixed and stained with a Hemacolor ${ }^{\circledR}$ (Merck) kit. Histological sections and imprints were examined with light microscopy for disease diagnosis.

\section{Transmission electron microscopy}

Cockles with extremely thin meat from Lombos do Ulla and O Sarrido were selected for TEM. Small pieces of digestive gland were taken and fixed in $2.5 \%$ glutaraldehyde in filtered seawater for $2 \mathrm{~h}$ at $4^{\circ} \mathrm{C}$, post-fixed in $1 \%$ osmium tetroxide in $0.2 \mathrm{M}$ sodium cacodylate solution and embedded in Epon resin. Ultrathin sections (50 to $70 \mathrm{~nm}$ ) were stained with uranyl acetate and lead citrate and examined under a JEM-1010 transmission electron microscope (JEOL).

\section{Molecular characterisation}

\section{Genomic DNA extraction}

A small piece of digestive gland from cockles from Lombos do Ulla and O Sarrido in June 2012 were preserved in $96 \%$ ethanol for molecular analysis. DNA extractions were performed employing the commercial Wizard Genomic DNA Purification Kit (Promega), according to the manufacturer's protocol for isolating genomic DNA from animal tissue. DNA quality and quantity were checked in a spectrophotometer (Nanodrop ${ }^{\circledR}$ ND-1000, Nanodrop Technologies).

\section{PCR amplification}

Primers previously published and primers newly designed in this study (Table 1) were used to amplify overlapping fragments of the intergenic spacer (IGS) region, the first internal transcribed spacer (ITS1) and 
Table 1. Sequences of the primers used in this study together with their position within the GenBank sequence KF278722. The purpose of all primers in this study was molecular characterisation, except Mcoch-F and Mcoch-R, which were used for diagnosis

\begin{tabular}{|llcl|}
\hline Primer & Sequence $\left(5^{\prime}-3^{\prime}\right)$ & Location & Source \\
\hline IN-4 & AGG CTC GCT GTC AAG CGG CG & $1-20$ & López-Flores et al. (2004) \\
IN-2 & GTC TAT CAC TCG CGC TCG TC & $717-736$ & López-Flores et al. (2004) \\
MT-2B & CGA TCG AGT AAG TGC ATG CA & $1269-1288$ & López-Flores et al. (2004) \\
18S & TTG CGC GCC GAA GCA CGC TA & $2244-2263$ & López-Flores et al. (2004) \\
MartCIGS446 & CAT TCG GAA ATT TCA CGC TAA & $446-466$ & Newly designed \\
MartCIGS1507 & GCC AGC TAT GGC ACA ACA TA & $1507-1526$ & Newly designed \\
MartCIGS1809 & GGC GTC TCC GAA CTA GAC TC & $1809-1828$ & Newly designed \\
MartC18S2639 & GTT GCG ACT ACG GAC GTT TT & $2639-2658$ & Newly designed \\
SS1 & ATA TTA ATC CAC GGC GTG GAC & $2297-2317$ & Berthe et al. (2000) \\
CAS2 & ACG GGC GGT GTG ACA AAG G & $3640-3658$ & Berthe et al. (2000) \\
Mart18S3564 & GGA TTG CAA TTG TTC CTC GT & $3564-3583$ & Newly designed \\
Mart18S3755 & GGG ACC GTG TTA CGA CTT GT & $3755-3774$ & Newly designed \\
Pr3 & CAG ACT GCA CTT CGG TGC GG & $3698-3718$ & Le Roux et al. (2001) \\
Pr5 & CTC GCG AGT TTC GAC AGA CG & $4414-4433$ & Le Roux et al. (2001) \\
Mcoch-F & CTC TGT CCG GTC AAA GCC TA & $3890-3909$ & Newly designed \\
Mcoch-R & AAT TCG CAG CCC ACA AAG & $4191-4208$ & Newly designed \\
\hline
\end{tabular}

the small subunit rRNA gene (18S) of the Marteilia parasite infecting Galician cockles that had been previously diagnosed by histology. All PCR assays were performed in a total volume of $25 \mu \mathrm{l}$ containing $1 \mu \mathrm{l}$ of genomic DNA (200 ng), PCR buffer at $1 \times$ concentration, $1.5 \mathrm{mM} \mathrm{MgCl}_{2}, 0.2 \mathrm{mM}$ nucleotides (Roche Applied Science), $0.3 \mu \mathrm{M}$ of each pair of primers used in the molecular characterisation and $0.025 \mathrm{U} \mathrm{Hl}^{-1} \mathrm{Taq}$ DNA polymerase (Roche Applied Science). A negative control (no DNA) was used in each PCR assay. The PCR assays were carried out in a Tgradient thermocycler (Biometra), under the following reaction conditions: $94^{\circ} \mathrm{C}$ for $2 \mathrm{~min} ; 35$ cycles at a melting temperature of $94^{\circ} \mathrm{C}$ for $1 \mathrm{~min}$, an annealing temperature of $55^{\circ} \mathrm{C}$ for $1 \mathrm{~min}$, and an extension temperature of $72^{\circ} \mathrm{C}$ for $1 \mathrm{~min} 30 \mathrm{~s}$; followed by a final extension period of $72^{\circ} \mathrm{C}$ for $7 \mathrm{~min}$. After PCR, $10 \mu \mathrm{l}$ of amplified DNA were analysed by electrophoresis on $2 \%$ agarose gels, in $1 \%$ Tris acetate EDTA buffer, stained with ethidium bromide and scanned in a GelDoc XR documentation system (BioRad).

\section{Cloning and sequencing}

The PCR products were ligated into cloning vector pCR2.1 at $14^{\circ} \mathrm{C}$ overnight and transformed into Escherichia coli One Shot Top 10F' Chemically Competent cells (Invitrogen Life Technologies ${ }^{\mathrm{TM}}$ ). Transformed cells were screened by PCR using the pair of primers M13 forward (5'-GTA AAA CGA CGG CCA G-3') and reverse (5'-CAG GAA ACA GCT ATG AC$\left.3^{\prime}\right)$. Ten positive clones of the ITS1 region and 3 clones of each fragment of IGS and 18S regions were cleaned for sequencing using ExoSap-It (USB) for $15 \mathrm{~min}$ at $37^{\circ} \mathrm{C}$, followed by an inactivation of $15 \mathrm{~min}$ at $80^{\circ} \mathrm{C}$. Sequencing was performed by the company Secugen (Madrid) using M13F and M13R primers, and the chromatograms were analysed using Chromas Pro v.1.41 (Technelysium). All generated sequences were searched for similarity using the Basic Local Alignment Search Tool (BLAST) through web servers of the National Center for Biotechnology Information and were then aligned using the Clustal $\mathrm{W}$ multiple alignment in the program MEGA to exclude the homologous regions and produce the entire IGS-18SITS1 region of the rRNA gene.

\section{Phylogenetic analyses of ITS1 and IGS regions}

Phylogenetic analyses were performed using sequences of the Marteilia parasite infecting Galician cockles obtained in this study. Ten sequences of clones of the ITS1 region and 3 sequences of clones of the IGS region obtained in this study were aligned with sequences of $M$. cochillia from Catalonia and of M. refringens available in GenBank; because of the high number of deposited sequences of the latter species, several were selected covering various hosts and geographic ranges (Table 2). The alignments were performed using the Clustal W algorithm (Thompson et al. 1994) in MEGA v 4.1 software (Tamura et al. 2007) under default parameters. The aligned sequences were cut and adjusted manually and subjected to phylogenetic analyses. Neighbourjoining (NJ) phylogenetic trees, using the maximum composite likelihood model, and maximum parsi- 
Table 2. Marteilia refringens and M. cochillia. Sequences of first internal transcribed spacer (ITS1) and intergenic spacer (IGS) regions deposited in GenBank used in phylogenetic analysis

\begin{tabular}{|c|c|c|c|c|}
\hline Locus & GenBank accession & Marteilia species & Host & Location \\
\hline \multirow[t]{9}{*}{ ITS1 } & JN820085-89 & M. cochillia & Cerastoderma edule & Catalonia (Spain) \\
\hline & AB534169 & M. refringens & Mytilus sp. & Italy \\
\hline & AJ629351 & M. refringens & Mytilus galloprovincialis & Venice (Italy) \\
\hline & AJ629348 & M. refringens & Mytilus galloprovincialis & Trieste (Italy) \\
\hline & AJ629343 & M. refringens & Mytilus galloprovincialis & Vigo (Spain) \\
\hline & AJ629341 & M. refringens & Mytilus galloprovincialis & Huelva (Spain) \\
\hline & JX119021 & M. refringens & Ostrea stentina & Tunisia \\
\hline & AJ629336 & M. refringens & Ostrea edulis & Huelva (Spain) \\
\hline & DQ426626 & M. refringens & Ostrea edulis & Greece \\
\hline \multirow[t]{11}{*}{ IGS } & JN820091-92 & M. cochillia & Cerastoderma edule & Catalonia (Spain) \\
\hline & $\mathrm{KF} 314809-11^{\mathrm{a}}$ & M. cochillia & Cerastoderma edule & Catalonia (Spain) \\
\hline & AJ629376 & M. refringens & Mytilus galloprovincialis & Venice (Italy) \\
\hline & AJ629369 & M. refringens & Mytilus galloprovincialis & Vigo (Spain) \\
\hline & AM504149 & M. refringens & Mytilus galloprovincialis & Catalonia (Spain) \\
\hline & AJ629362 & M. refringens & Mytilus galloprovincialis & Huelva (Spain) \\
\hline & AJ629373 & M. refringens & Mytilus galloprovincialis & Trieste (Italy) \\
\hline & AM748040 & M. refringens & Solen marginatus & Huelva (Spain) \\
\hline & EU854304 & M. refringens & Xenostrobus securis & Vigo (Spain) \\
\hline & AM292652 & M. refringens & Chamelea gallina & Balearic Islands (Spain) \\
\hline & AJ629355 & M. refringens & Ostrea edulis & Huelva (Spain) \\
\hline
\end{tabular}

mony (MP) trees were generated with bootstrap values calculated over 1000 replicates. All positions containing gaps and missing data were eliminated from the dataset. $M$. sydneyi was not included in these analyses because no IGS fragment sequence of this species has been deposited in GenBank. Moreover, the deposited ITS1 fragment sequences of $M$. sydneyi only overlap with deposited fragments of the Marteilia parasite infecting cockles in Galicia and 1 deposited fragment of $M$. refringens. To estimate evolutionary divergence between sequences, a pairwise distance estimation was calculated using the maximum composite likelihood method in MEGA 4. All positions containing gaps and missing data were eliminated from the dataset. The sequences compared were 1 ITS1 fragment of the Marteilia parasite infecting cockles from Galicia (KF263910), M. refringens (AJ250699) and M. sydneyi (AF159248).

\section{PCR assay for the detection of Marteilia cochillia}

A PCR assay was designed with the aim of easily detecting $M$. cochillia in samples from areas where this parasite co-occurs with $M$. refringens. Two specific primers were designed based on the ITS1 region of the Marteilia parasite infecting Galician cockles: Mcoch-F and Mcoch-R (Table 1). For this, the 10 ITS1 DNA sequences of the Marteilia parasite infecting
Galician cockles obtained in this work were aligned using the program Clustal W together with 3 ITS-1 sequences of $M$. refringens and 1 sequence of $M$. sydneyi previously deposited in GenBank: Marteilia parasitising Cerastoderma edule from Galicia (KF263910KF263919), M. refringens (AB513427 and AB534169) infecting Mytilus sp. from Italy, $M$. refringens (AJ629336) infecting Ostrea edulis from Spain and M. sydneyi infecting Saccostrea glomerata from Australia (AY504631). Sequences of other Paramyxida, such as Marteilioides chungmuensis or Paramyxa sp. from the amphipod Echinogammarus marinus, were not included because no ITS1 sequences of these species have been deposited in GenBank. Subsequently, the specific primers for the Marteilia parasite infecting Galician cockles were designed using the program Primer 3 (Rozen \& Skaletsky 2000). PCR assays were performed in a total volume of $25 \mu \mathrm{l}$ containing $1 \mu$ l of genomic DNA (200 ng), PCR buffer at $1 \times$ concentration, $1.5 \mathrm{mM} \mathrm{MgCl}, 0.2 \mathrm{mM}$ nucleotides (Roche Applied Science), $0.3 \mu \mathrm{M}$ each specific primer

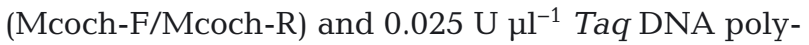
merase (Roche Applied Science). A positive control for the Marteilia parasite infecting Galician cockles and a negative control (no DNA) were used in every PCR assay. The optimal annealing temperature for the specific primers was determined with a temperature gradient and various incubation times. PCR assays were carried out in a Tgradient thermocycler 
(Biometra), under the following reaction parameters: $94^{\circ} \mathrm{C}$ for $2 \mathrm{~min} ; 35$ cycles at a melting temperature of $94^{\circ} \mathrm{C}$ for $30 \mathrm{~s}$, an annealing temperature of $58^{\circ} \mathrm{C}$ for $45 \mathrm{~s}$, and an extension temperature of $72^{\circ} \mathrm{C}$ for $1 \mathrm{~min}$, followed by a final extension period of $72^{\circ} \mathrm{C}$ for $1 \mathrm{~min}$. After PCR, $10 \mu \mathrm{l}$ of amplified DNA were analysed by electrophoresis on $2 \%$ agarose gels, in $1 \%$ Tris acetate EDTA buffer, stained with ethidium bromide and scanned in a GelDoc XR documentation system (BioRad). PCR products were cleaned and sequenced as described above in order to confirm their identity.

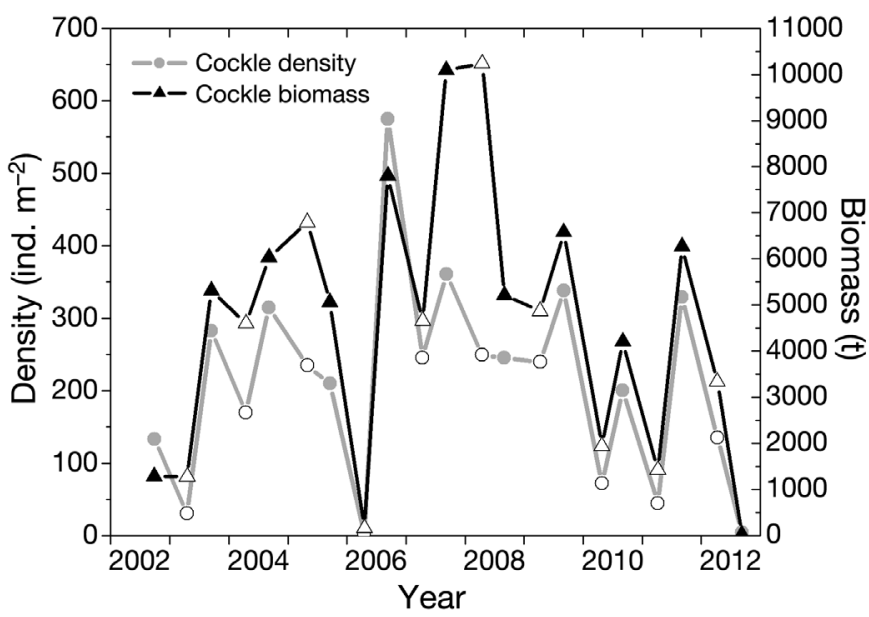

Fig. 3. Cerastoderma edule. Estimations of cockle density and cockle biomass in the shellfish bed Lombos do Ulla for the period 2002 to 2012. Two estimations were performed each year, one in September (just before the fishing season; filled symbols) and another in April (just after fishing season; open symbols)

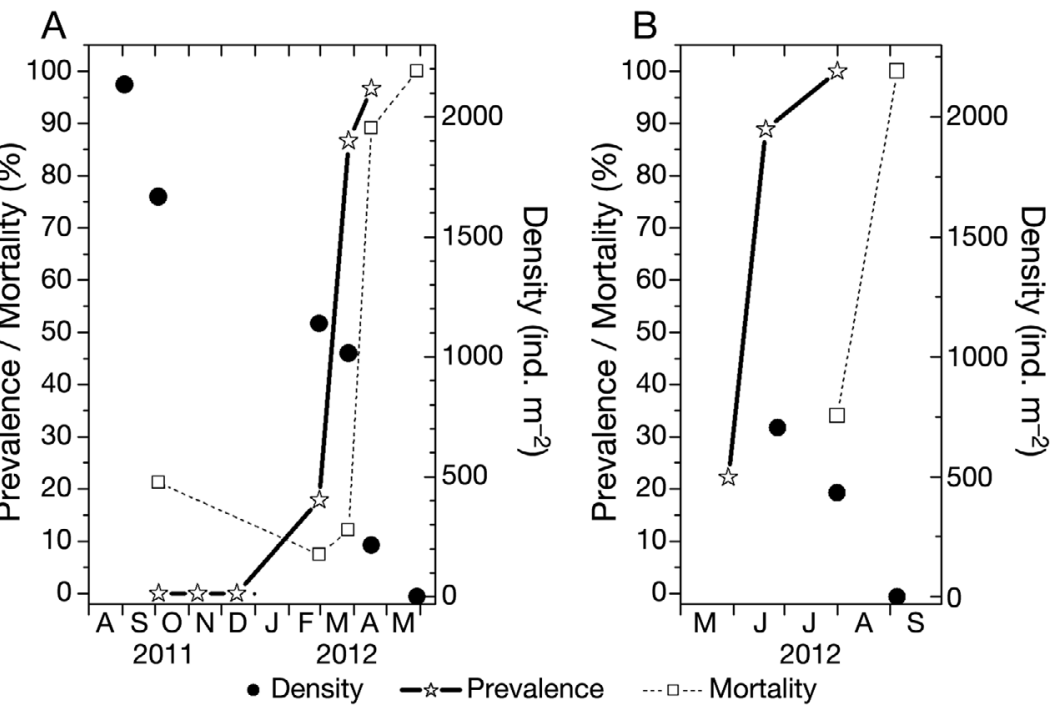

Fig. 4. Cerastoderma edule. Temporal variation of density, mortality and prevalence of marteiliosis corresponding to the cockle cohorts recruited in (A) 2011 and (B) 2012
The analytical specificity of the primers was evaluated using cockles Cerastoderma edule and mussels Mytilus galloprovincialis collected from the Ría de Arousa and oysters Ostrea edulis collected from Brittany (France). All of these molluscs were diagnosed for marteiliosis using the genus-specific PCR assay described by López-Flores et al. (2004) followed by sequencing the amplicon to identify the Marteilia species. Thus, genomic DNA extracted from 25 cockles positive for $M$. cochillia, 5 mussels positive for $M$. refringens, 10 oysters positive for $M$. refringens, and 25 cockles, 10 mussels and 10 oysters that were negative for the genus Marteilia, was used to perform specific PCR assays with the primer pair Mcoch-F/ Mcoch-R as described above.

\section{RESULTS}

\section{Cockle abundance in Lombos do Ulla}

The estimations of cockle biomass and cockle density in the shellfish bed of Lombos do Ulla for the period 2002 to 2012 are shown in Fig. 3. The mean values of density and biomass for the period were 210 ind. $\mathrm{m}^{-2}$ and $4628 \mathrm{t}$. The sharpest decreases to minimal values of both variables were recorded in April 2006 and September 2012. When values below the mean were recorded in a spring sampling (immediately after the end of the fishing season), both variables tended to increase in the next sampling (recovery of the population). Consistently, the sharp decrease of cockle abundance recorded in April 2006 was followed by a sharp increase. However, cockle abundance did not increase after the end of the 20112012 fishing season (April 2012 sampling), but it sharply decreased to the minimal values recorded in September 2012, when live cockles were seldom found (density: 5 ind. $\mathrm{m}^{-2}$ ) throughout the whole bed.

A sharp increase in mortality of the cohort recruited in 2011 was detected between March and April 2012, which was associated with a decrease in density (Fig. 4A). In the May 2012 sampling, mortality was $100 \%$. In the cohort recruited in 2012, which was first detected in May 2012, density decreased from the first record (June 2012) and reached 0 by August 2012 (Fig. 4B). 


\section{Cockle mortality recorded in submersed boxes}

Cockle mortality recorded monthly in submersed boxes showed high variability through the period 2007 to 2012 (Fig. 5). It reached values higher than $50 \%$ in April 2009 (69\%), November 2009 (92\%),

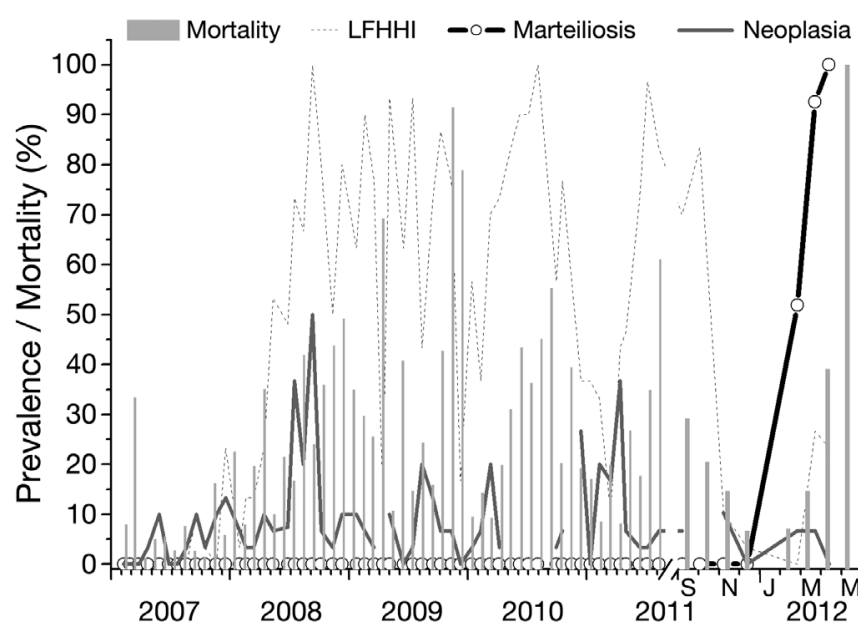

Fig. 5. Cerastoderma edule Monthly records of mortality and prevalence of a pathological condition characterised by large foci of heavy haemocytic infiltration (LFHHI), disseminated neoplasia and marteiliosis. There is a break in the $x$ axis to show the period September 2011 to May 2012 with higher resolution

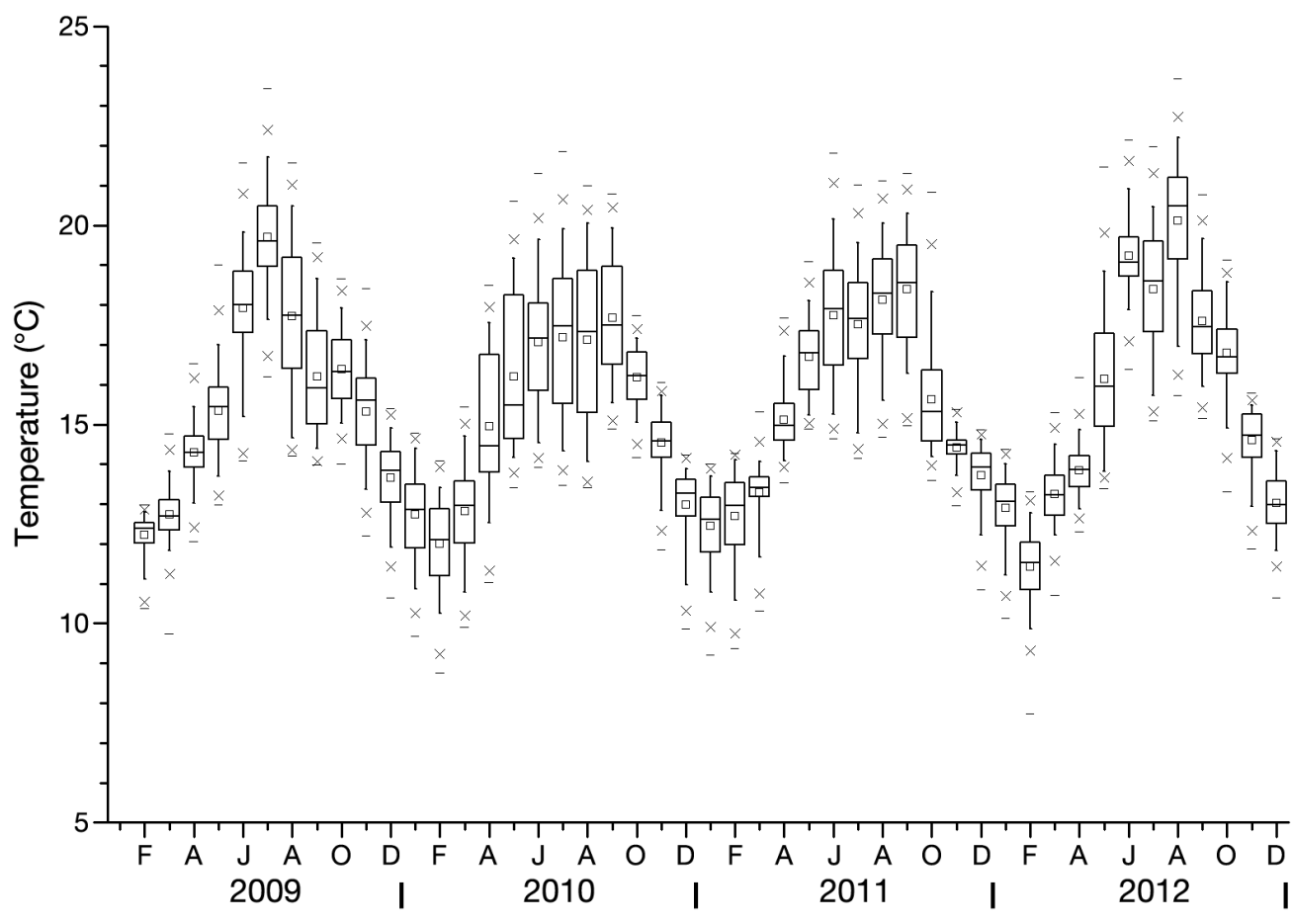

Fig. 6. Temperature at monthly intervals through the period 2009 to 2012 , calculated from records of a sensor set in a box with cockles, placed in the bottom of Lombos do Ulla. Dot: mean; bar within the box: median; box: 25th-75th percentile; whiskers: 5th-95th percentile; outlier crosses: 1st-99th percentile; outlier bars: min.-max. values
December 2009 (79\%), September 2010 (55\%), August 2011 (61\%) and May 2012 (100\%). The high December 2009, within the fishing season, was associated with a decrease of cockle abundance in the bed in the next bed sampling (April 2010; Fig. 3). More dramatically, the $100 \%$ mortality recorded in the boxes in May 2012, when the fishing season had finished, was associated with minimal cockle abundance in the bed in the subsequent bed sampling (September 2012; Fig. 3).

\section{Seawater temperature and salinity in Lombos do Ulla}

The sensor set in 1 box with cockles in Lombos do Ulla provided records of seawater temperature from January 2009. The monthly mean temperature ranged from 12.0 to $19.7^{\circ} \mathrm{C}$ in the period 2009 to 2010 , from 12.5 to $18.4^{\circ} \mathrm{C}$ in 2011 and from 11.4 to $20.1^{\circ} \mathrm{C}$ in 2012 (Fig. 6). The comparison of monthly mean temperature between 2012 and the period 2009 to 2010 showed values of $1.7^{\circ} \mathrm{C}$ and $2.7^{\circ} \mathrm{C}$ higher in June 2012 and August 2012, respectively. Temperatures in 2011 were 0.5 to $1.5^{\circ} \mathrm{C}$ higher than those of the period 2009 to 2010, except in January, July and October. mortality recorded in the boxes in November and 


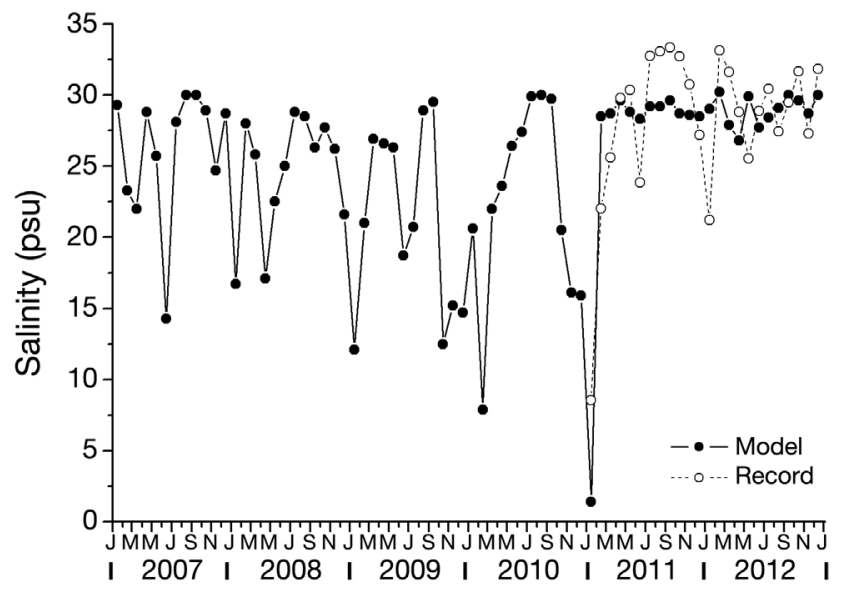

Fig. 7. Monthly minimum values of salinity in Lombos do Ulla for the period 2007 to 2012. Solid line with solid circles: values for the bottom water in the centre of the estuary obtained through a model integrating net rainfall in the river basin, wind direction and force, and tidal amplitude. Dashed line with open circles: values recorded with a sensor set in a box with cockles, placed in the bottom of Lombos do Ulla

The monthly minimum values of salinity of bottom water in Lombos do Ulla, obtained from a model integrating net rainfall in the river basin, wind direction and force, and tidal amplitude, ranged from 7.9 to 28.5 psu in the period 2007 to 2010 (Fig. 7). In 2011 and 2012, the monthly minimum values of salinity predicted by the model were higher (28.3-29.0 psu in 2011 and 26.8-30.2 psu in 2012), except in January 2011 (1.4 psu; Fig. 7). Considering the records of the sensor set in the box with cockles, the monthly minimum values of salinity were close to those obtained with the model, with deviations (lower than 8 psu) only in January 2011 and January 2012 (Fig. 7). A single episode of critical salinity values for cockle survival (Parada et al. 2012) was recorded in the period 2011 to 2012, in January 2011, when salinity records at high tide in the box were below 10 psu for 2 consecutive days and below 5 psu on 1 day.

\section{Cockle pathological conditions in Lombos do Ulla}

Three serious pathological conditions were found by examination of histological sections of adult cockles (length $>25 \mathrm{~mm}$ ) from Lombos do Ulla: disseminated neoplasia, a condition characterised by large foci of heavy haemocytic infiltration (LFHHI) of the connective tissue, and marteiliosis. The prevalence of disseminated neoplasia was $<15 \%$ in most samples of adult cockles in the period 2007 to 2012 (Fig. 5). Higher prevalence values (up to $50 \%$ ) of dissemi- nated neoplasia did not coincide with the highest mortality values. The condition characterised by LFHHI showed frequent high prevalence values (up to $100 \%$ ) in that period, which occasionally coincided with high mortality ( $>50 \%$; Fig. 5). In 2012, when mortality reached $100 \%$, the prevalence of LFHHI was $<30 \%$, i.e. among the lower values of the period. Marteiliosis was absent in the samples for most of the period 2007 to 2012. It was detected for the first time in February 2012, with a prevalence of $52 \%$; its prevalence rose to $93 \%$ in March 2012 and $100 \%$ in April 2012; this marteiliosis outbreak coincided with the heaviest mortality record (Fig. 5).

The only pathological condition found in the samples from cohorts recruited in 2011 and 2012 was marteiliosis. In the former, marteiliosis was not detected in the samples of 2011 but it was detected for the first time in February 2012, as in the adult cockles. Its prevalence increased from $18 \%$ in February to $87 \%$ in March and $97 \%$ in April 2012, coinciding with a sharp increment in mortality and decrease in density (Fig. 4A) up to disappearance of the cohort. In the cohort recruited in 2012, marteiliosis was detected in the first sample (late May 2012) with a prevalence of $22 \%$, which sharply increased to $89 \%$ in June and $100 \%$ in August 2012, concurrently with decreasing abundance up to disappearance of the cohort (Fig. 4B).

No case of marteiliosis was detected in the samples of 30 carpet-shell clams Ruditapes decussatus and 30 Manila clams R. philippinarum collected in April 2012.

\section{Information from other cockle beds}

Marteiliosis was detected in all sampled beds in the Ría de Arousa except in one. The prevalence of marteiliosis, based on examination of histological sections, ranged from $100 \%$ in the most estuarine bed (Carril) to $0 \%$ in the nearest to ocean bed (Moreiras; Table 3). In the beds where marteiliosis was detected, examination of histological sections disclosed more cases than imprints did. The cockle catch from the whole Ría de Arousa in the first 4 mo of 2012 was similar to the mean values of the period 1997 to 2011; in May 2012, it sharply decreased and was negligible from August to December (Fig. 8). For instance, the catch was $0.013 \mathrm{t}$ in November 2012 while the November catch average in the period 1997 to 2011 was $170 \mathrm{t}$. There was no record of negligible cockle catch in the period 1997 to 2011, even in the year 2006 (Fig. 8), when cockle abundance in Lombos do Ulla showed a minimum 
Table 3. Prevalence of marteiliosis, based on examination of imprints and histological sections, in the samples taken from beds other than Lombos do Ulla in 2012; na: not available

\begin{tabular}{|c|c|c|c|c|c|}
\hline \multirow[t]{2}{*}{ Ría } & \multirow[t]{2}{*}{ Location } & \multirow{2}{*}{$\begin{array}{l}\text { Sampling date } \\
\text { (d/mo) }\end{array}$} & \multirow{2}{*}{$\begin{array}{c}\text { Length } \\
(\text { mean } \pm \mathrm{SD}, \mathrm{mm})\end{array}$} & \multicolumn{2}{|c|}{ _ Prevalence (\%) } \\
\hline & & & & Imprints & Histology \\
\hline Arousa & Carril & $02 / 05$ & $27.4 \pm 1.5$ & na & 100 \\
\hline Arousa & O Sarrido (Cambados) & $04 / 06$ & $31.6 \pm 2.1$ & 26.7 & 33.3 \\
\hline Arousa & Moreiras (O Grove) & $20 / 06$ & $25.9 \pm 3.4$ & 0.0 & 0.0 \\
\hline Arousa & As Aceñas (Illa de Arousa) & $20 / 06$ & $27.9 \pm 3.4$ & 70.0 & 75.0 \\
\hline Arousa & Praia de Barraña (Cabo de Cruz) & 05/06 & $29.6 \pm 1.3$ & 13.3 & 23.3 \\
\hline Arousa & Praia de Raposiños (Pobra do Caramiñal) & $05 / 06$ & $28.8 \pm 2.5$ & 26.7 & 43.3 \\
\hline Arousa & Praia de Cruces (Palmeira) & 03/07 & $30.6 \pm 2.6$ & 48.3 & 55.0 \\
\hline O Barqueiro & Villabril (Vicedo) & $18 / 06$ & $34.5 \pm 2.5$ & 0.0 & 0.0 \\
\hline Ferrol & Praia de Maniños (Barallobre) & $20 / 06$ & $30.6 \pm 3.1$ & 0.0 & 0.0 \\
\hline Ortigueira & O Ladrido (Espasante) & $11 / 06$ & $32.6 \pm 1.8$ & 0.0 & 0.0 \\
\hline Betanzos & Lombo da Espiñeira (Miño) & $18 / 06$ & $27.6 \pm 2.1$ & 0.0 & 0.0 \\
\hline Corme-Laxe & Rio Anllóns & $29 / 05$ & $35.3 \pm 2.4$ & 0.0 & 0.0 \\
\hline Camariñas & Río da Ponte & 04/06 & $30.3 \pm 2.0$ & 0.0 & 0.0 \\
\hline Muros & A Misela (Noia) & $30 / 05$ & $35.7 \pm 4.2$ & 0.0 & 0.0 \\
\hline Muros & Testal (Noia) & $30 / 05$ & $29.9 \pm 2.3$ & 0.0 & 0.0 \\
\hline Muros & Praia da Virxe (Muros) & 06/06 & $33.3 \pm 2.9$ & 0.0 & 0.0 \\
\hline Pontevedra & Praceres (Lourizán) & $06 / 06$ & $31.7 \pm 1.4$ & 0.0 & 0.0 \\
\hline Vigo & Praia de Cesantes (Redondela) & $18 / 06$ & $31.5 \pm 2.4$ & 0.0 & 0.0 \\
\hline
\end{tabular}

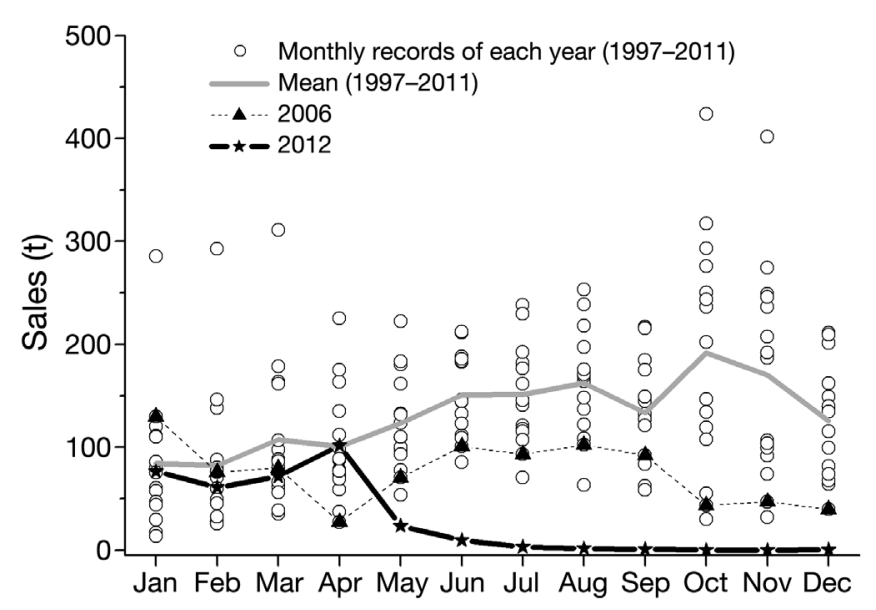

Fig. 8. Cerastoderma edule. Monthly records of sales of cockles caught in the Ría de Arousa corresponding to the period 1997 to 2011, the year 2006 and the year 2012. The mean values of the period 1997 to 2011 are also shown

(Fig. 3). No case of marteiliosis was detected in the beds located in other rías (Table 3).

\section{Light microscopy observations of marteiliosis}

Histological sections of cockles affected by marteiliosis showed the different stages of the sporulation cycle of parasites of the genus Marteilia in the epithelium of the digestive diverticula. The most common parasite stages in all infected cockles were ellipsoidal primary cells, up to $33 \mu \mathrm{m}$ long and $21 \mu \mathrm{m}$ wide, enclosing rounded to ellipsoidal sporangia (secondary cells), up to $15 \mu \mathrm{m}$ long, which contained rounded, more or less mature spores (tertiary cells), ca. $3 \mu \mathrm{m}$ in diameter (Fig. 9A,B). Six spores per sporangium and up to 8 sporangia per primary cell were counted while examining consecutive histological sections. The spores appeared within vacuoles of the sporangium, with an apparently empty space between the spore and the vacuole boundary except for a reduced contact area. Both the cytoplasm of sporangia and the spores changed from basophilic to acidophilic as spores matured. Primary cells, 5 to $12 \mu \mathrm{m}$ long, with acidophilic cytoplasm, containing basophilic secondary cells with no tertiary cell inside, were also observed (Fig. 9C); primary cells containing a single nucleus with a patent nucleolus but no secondary cells were rarely seen. Frequently, all digestive tubules appearing in a histological section of cockles were infected, with the parasites occupying large areas of tubule epithelium, but infected cockles with some areas of the digestive gland free of parasites were also found. Some presporulation stages were occasionally observed in the epithelium of stomach branches (Fig. 9D). The intestine of heavily infected cockles showed numerous free sporangia included in the faeces. Occasionally, some area of the digestive gland of infected cockles showed heavy haemocytic infiltration of the connective tissue associated with destruction of digestive tubules, while the remaining digestive gland showed no haemocytic reaction. Some primary cells showed 

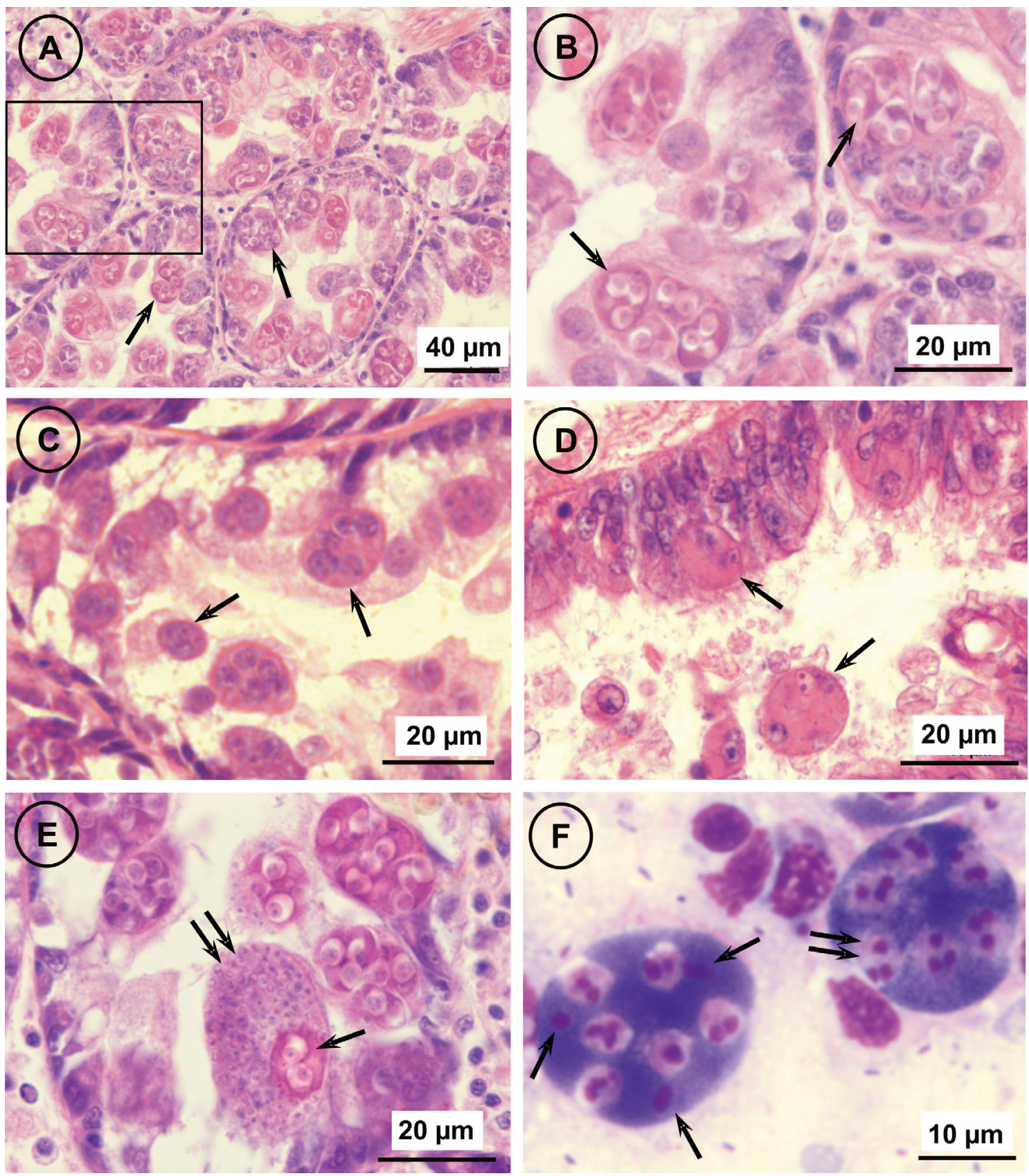

Fig. 9. Marteilia sp. infecting Cerastoderma edule. Light micrographs of the aetiological agent of marteiliosis affecting cockles in the Ría de Arousa. (A) Histological section through the digestive gland of a cockle showing the epithelium of digestive tubules densely occupied by the parasite (arrows) (Harris' haematoxylin and eosin, H\&E). (B) Higher magnification of the previous image showing parasite sporulation stages (arrows), in which each primary cell encloses sporangia with maturing spores. (C) Histological section through the digestive gland of a cockle showing the epithelium of a digestive tubule infected with presporulation stages of the parasite (arrows) consisting of primary cells enclosing presporulating secondary cells (H\&E). (D) Histological section through a stomach branch of a cockle showing presporulation stages (arrows) of the parasite in the epithelium and lumen (H\&E). (E) Histological section of a cockle through the digestive gland showing a primary cell of the parasite whose cytoplasm is hyperparasitised by microsporidian-like spores (double arrow); that primary cell also encloses a sporangium (arrow) with spores (H\&E). (F) Micrograph of an imprint of the digestive gland of a cockle showing 2 parasite sporangia containing 6 spores (double arrow) each; the sporangium on the left shows 3 sporangial nuclei (arrows). Note the finely granulated extrasporal cytoplasm of sporangia (Hemacolor ${ }^{\circledR}$ ) 
their cytoplasm hyperparasitised with a microsporidian-like organism; in those cases, the number of sporangia (or presporangia) within the primary cell was lower than in non-hyperparasitised ones (Fig. 9E). The percentage of cockles affected by marteiliosis that showed the microsporidian-like hyperparasite was $90 \%$ in Carril, 69\% in O Sarrido, 23\% in Raposiños, $31 \%$ in Cruces and $0 \%$ in the remaining locations. Free parasite sporangia were observed in the imprints of the digestive gland from most infected cockles. The sporangia enclosed 6 spores, which showed up to 3 very small nuclei. Up to 3 nuclei were observed in the extraspore sporangial cytoplasm. The cytoplasm of the sporangia appeared finely granulated (Fig. 9F).

\section{TEM observations on marteiliosis}

The earliest observed stage corresponded to a primary cell enclosing a single secondary cell (Fig. 10A). Primary cell cytoplasm contained numerous ribosomes, vermiform (ca. $45 \mathrm{~nm}$ in diameter, up to $430 \mathrm{~nm}$ long) and oblate $(200 \times 170 \mathrm{~nm})$ haplosporosomes, some multivesicular bodies (MVBs) and paracrystalline structures. The latter consisted of alternating electrondense and lighter layers, each ca. $25 \mathrm{~nm}$ thick. These paracrystalline structures resulted from piling folded membranes (Fig. 10B). Images of haplosporosomes emerging from MVBs (Fig. 10C) suggested a role of MVBs in haplosporosome assembly. Globular and kidney shaped mitochondria were also observed, as well as endoplasmic reticulum. The nucleus of the primary cell showed an oval outline and contained a nucleolus (Fig. 10A). The envelope of the primary cell (ca. 25-30 nm thick) showed light undulation (Fig. 10A,B) and consisted of 2 membranes with material between them; the outer membrane corresponded to the host vacuole hosting the parasite and the inner membrane to the parasite plasmatic membrane; osmiophilic materials appeared added to the inner side in some sections of the envelope (Fig. 10B). As sporulation progressed, the cytoplasm of the pri-
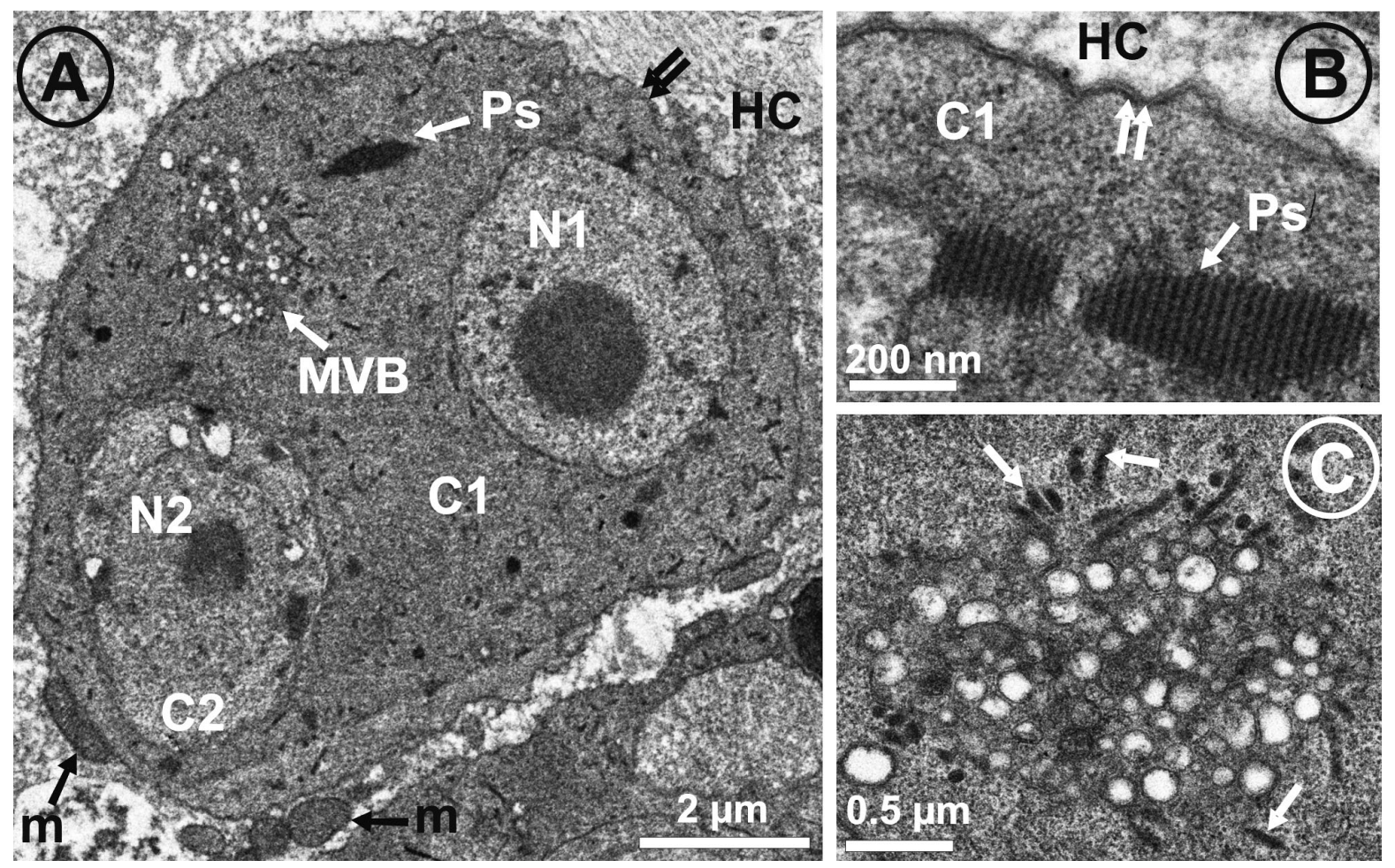

Fig. 10. Marteilia sp. infecting Cerastoderma edule. Transmission electron micrographs of the aetiological agent of marteiliosis affecting cockles in the Ría de Arousa. (A) Primary cell (C1) enclosing a secondary cell (C2); a paracrystalline structure (Ps) and a multivesicular body (MVB) are visible in the cytoplasm of $\mathrm{C} 1$ as well as mitochondria (m) of the host cell (HC) in close proximity to $\mathrm{C} 1$; note the wavy surface (double arrow) of the envelope of $\mathrm{C} 1$. N1, nucleus of $\mathrm{C} 1$; N2, nucleus of C2. (B) Detail of a Ps in the cytoplasm of $\mathrm{C} 1$; note that the envelope (double arrow) of $\mathrm{C} 1$ consists of 2 membranes with material between them and osmiophilic material added to its inner side; HC, host cell. (C) Detail of the MVB in the cytoplasm of C1 with haplosporosomes (arrows) that seem to emerge from the MVB 
mary cell was occupied by secondary cells that became developing sporangia (Fig. 11A,B). Numerous host mitochondria appeared in contact with and in the proximity of the primary cells at different sporulation stages (Figs. 10A, 11A \& 12A).

Before sporulation started, secondary cells showed an oval nucleus enclosing a nucleolus, numerous ribosomes and some mitochondria (Fig. 10A). The envelope of secondary cells at that stage consisted of 2 membranes. At the early sporulation stage, secondary cells showed various nuclei, and cisternae of endoplasmic reticulum were progressively organised to demarcate areas around nuclei (Fig. 11A). Some spheroid membrane-limited granules, up to $150 \mathrm{~nm}$ in size, with electron-dense content were observed (Fig. 11A). As membrane delimitation progressed, the occurrence of tertiary cells within secondary cells became evident (Fig. 11B). Most mitochondria appeared included in the areas becoming tertiary cells. The tertiary cells initially contained a single nucleus; their cytoplasm had numerous ribosomes and some mitochondria but haplosporosomes were not observed at that stage. Individualisation of tertiary cells (spore precursors) became evident due to their progressive separation of their surface from the boundary of the vacuoles of the secondary cell where they were included (Fig. 11B). The number and size of the membrane-limited granules with electron-dense content occurring in the cytoplasm of the secondary cells increased as sporulation progressed (Figs. 11C,D \& 12A). Up to 147 granules were counted in an ultrathin section of a sporangium; the average diameter was $340 \mathrm{~nm}$ (225-570 nm; Fig. 11D). The envelope thickness of the secondary cells also increased, becoming a wall up to $90 \mathrm{~nm}$ thick; some filiform projections with a knob-like end were observed rising from the wall of sporangia enclosing mature spores (Fig. 11E).

Each tertiary cell evolved by successive division of the nucleus and cytoplasm delimitation, giving rise to a spore (Fig. 12A). Mature spores were spheroid or globose in shape, $3.81(3.5-4.3) \times 3.39(3.2-3.6) \mu \mathrm{m}$ in size, with an irregular outline. They consisted of 3 uninucleate sporoplasms, the outer sporoplasm, the intermediate sporoplasm included in the outer one and the inner sporoplasm included in the intermediate one (Fig. 12). The outer sporoplasm had a nucleus that sometimes showed a nucleolus; the outer sporoplasm also contained numerous ribosomes, endoplasmic reticulum cisternae, haplosporosomes, which were not present in immature tertiary cells, and some globular mitochondria. Most haplosporosomes were spheroid up to $200 \mathrm{~nm}$ in diameter, but some were slender and longer, up to $430 \times 50 \mathrm{~nm}$; their electron density varied widely (Fig. 12B). The progressive separation of the spore from the boundary of the vacuole where they were included led to a reduced area of contact between the mature spore and the sporangial cytoplasm; thus an almost empty space surrounded most of the surface of mature spores (Figs. 11C, 12 \& 13A). Thin anastomosing cytoplasmic projections from the outer sporoplasm into that surrounding space were frequently observed more or less developed in mature spores (Fig. 13A,B); those projections, which enclosed ribosomes and some haplosporosomes, could be the result of an imperfect retraction of the outer sporoplasm. Myelin whorls and winding membranes, some of them connecting the spore surface with the vacuole boundary (Figs. 12B \& 13A), were observed in that space. The envelope of the mature spore was ca. $10 \mathrm{~nm}$ thick. Various membrane layers were observed in the area of contact between the spore and the vacuole boundary, even with osmiophilic deposits in some case (Fig. 13C). Four concentric membranes in the boundary between the outer and the intermediate sporoplams were seen in some sections (Fig. 13E). The intermediate sporoplasm contained numerous ribosomes, more mitochondria than the other sporoplams, abundant smooth endoplasmic reticulum cisternae and double-membrane limited flattened vermiform vesicles, with a knob-like enlargement at each end and electrondense content (Fig. 13D); these vesicles were up to $550 \mathrm{~nm}$ long $\times 40 \mathrm{~nm}$ in diameter. Cisternae partially surrounding the nucleus in a double concentric arrangement were frequently observed. The mitochondria were globular, with electron-lucent content, although some of them showed fibrillar materials (Fig. 13F). A spheroid electron-dense granular deposit up to $330 \mathrm{~nm}$ in diameter was observed in some cases (Figs. 12A \& 13G). The inner sporoplasm contained numerous ribosomes, and up to 5 mitochondria were observed (Fig. 13G). No specific mitotic structure was observed in the micrographs.

\section{Molecular characterisation of the aetiological agent of cockle marteiliosis}

\section{Analysis of rDNA sequences}

The molecular characterisation carried out using primers included in Table 1 allowed obtaining a consensus sequence of $4433 \mathrm{bp}$ of the aetiological agent of cockle marteiliosis, containing a partial sequence of the IGS region, the complete 18S rRNA gene, and 


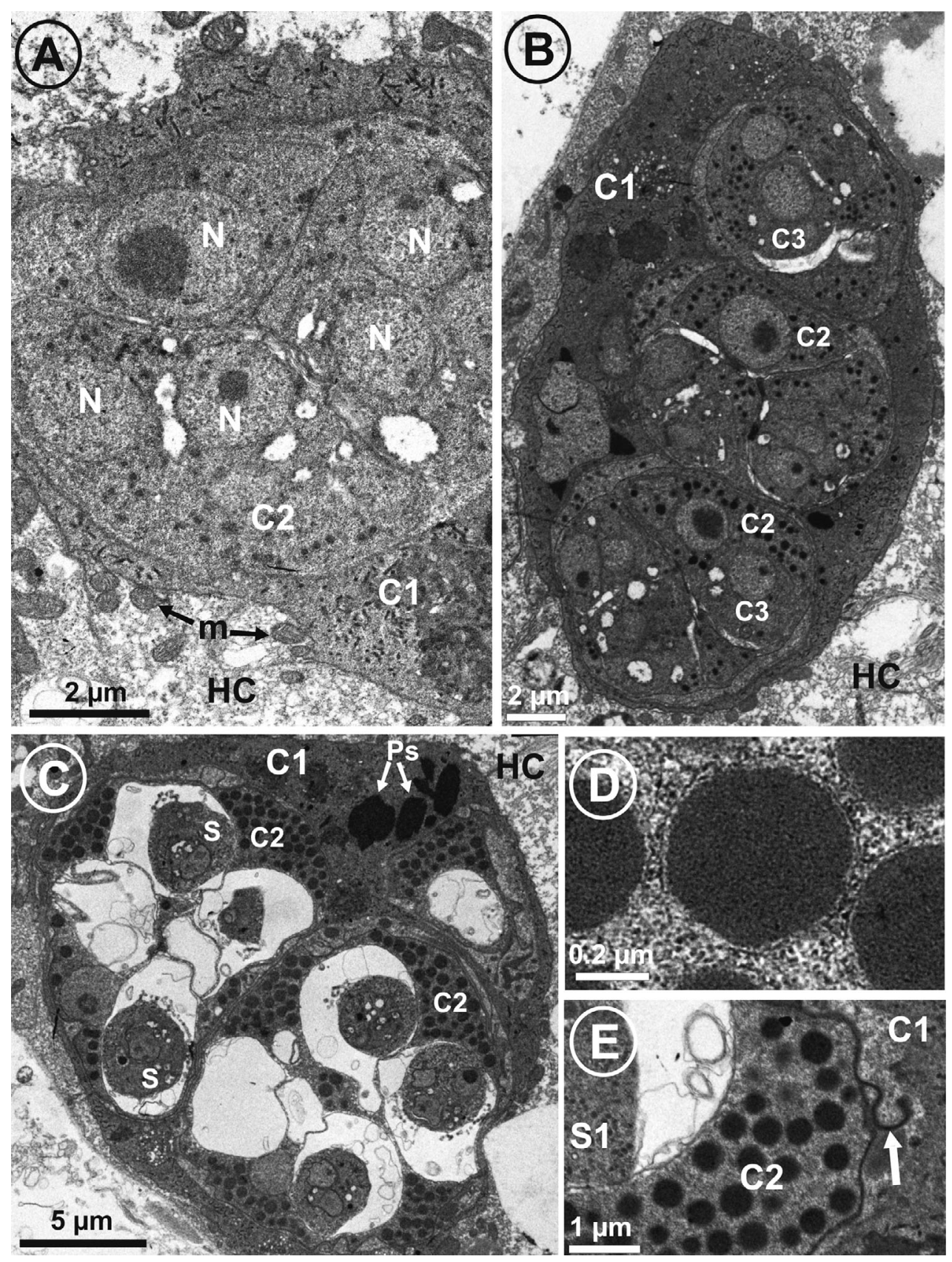

Fig. 11. Marteilia sp. infecting Cerastoderma edule. Transmission electron micrographs of the aetiological agent of marteiliosis affecting cockles in the Ría de Arousa. (A) Detail of a primary cell (C1) enclosing a secondary cell (C2) in the early process of differentiation to sporangium; 5 nuclei $(\mathrm{N})$ are observed inside $\mathrm{C} 2$; some areas of the cytoplasm of $\mathrm{C} 2$ are demarcated by cisternae of the endoplasmic reticulum; the cytoplasm of $\mathrm{C} 2$ shows some osmiophilic granules; mitochondria (m) of the host cell (HC) are observed in close proximity to $\mathrm{C} 1$, at the top and bottom of the micrograph. (B) C1 enclosing $3 \mathrm{C} 2 \mathrm{~s}$ in a more advanced stage of sporulation; tertiary cells (C3) can be distinguished within the C2s; the osmiophilic granules in the cytoplasm of the $\mathrm{C} 2 \mathrm{~s}$ are more numerous than in the previous micrograph; $\mathrm{HC}$, host cell. (C) $\mathrm{C} 1$ showing 3 sporangia (C2) enclosing spores (S); the cytoplasm of the sporangia have more and larger osmiophilic granules than in previous micrographs; the area of contact between the spores and the sporangial cytoplasm is reduced; HC, host cell; Ps, paracrystalline structure. (D) Detail of membrane limited osmiophilic granules in the extraspore sporangial cytoplasm. (E) Detail of an area of a sporangium (C2) showing a filiform projection (arrow) with a knob-like end rising from the wall of the sporangium; S1: outer sporoplasm of a spore 

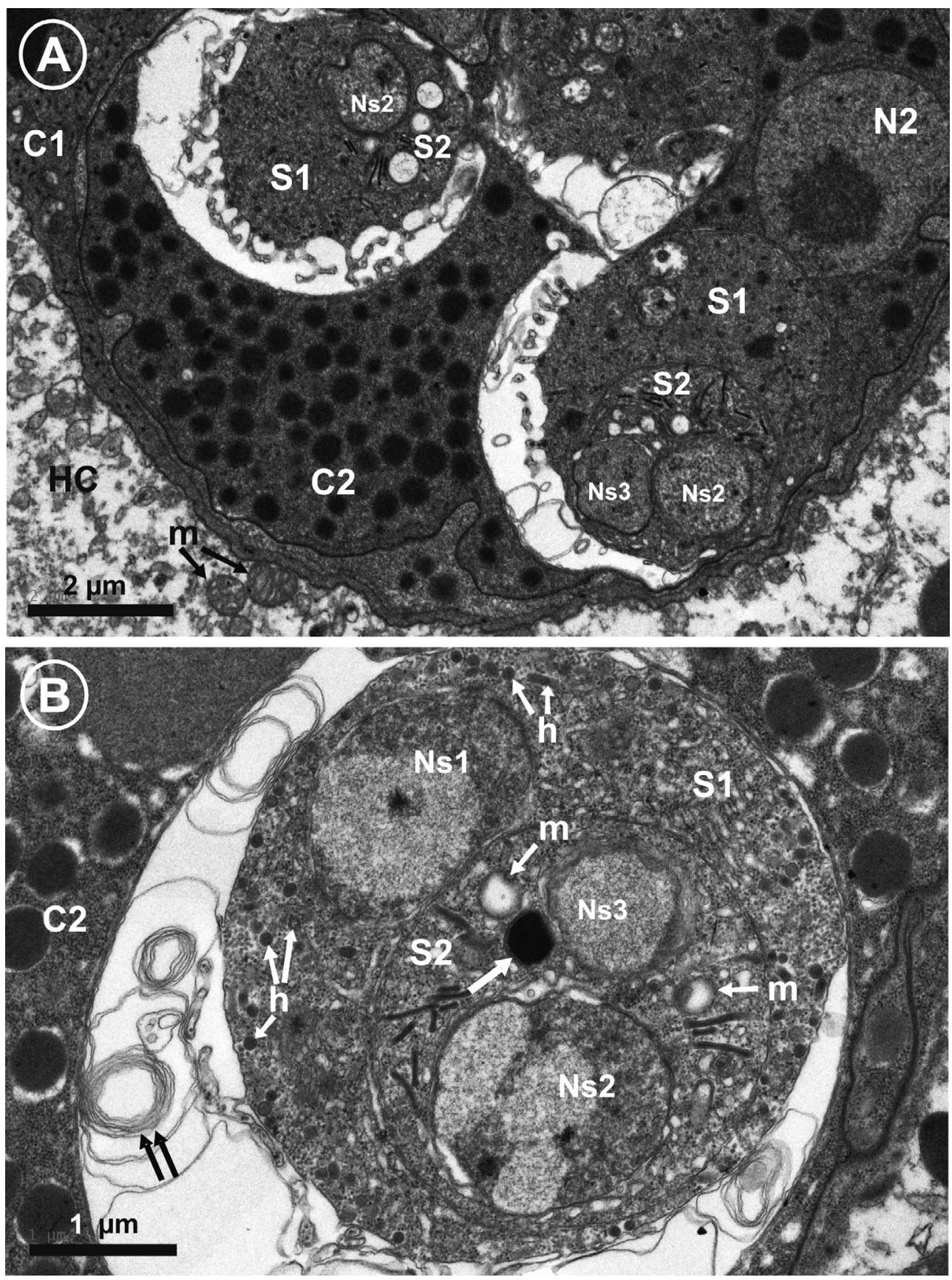

Fig. 12. Marteilia sp. infecting Cerastoderma edule. Transmission electron micrographs of the aetiological agent of marteiliosis affecting cockles in Ría de Arousa. (A) Detail of a sporangium (C2) within a primary cell (C1) enclosing maturing spores; the extraspore sporangial cytoplasm contains numerous osmiophilic granules; mitochondria (m) of the host cell (HC) are observed in close proximity to $\mathrm{C} 1 ; 3$ sporoplasms are distinguished in the spores; N2, nucleus of the sporangium; Ns2, nucleus of the intermediate sporoplasm; Ns3, nucleus of the inner sporoplasm; S1, outer sporoplasm; S2, intermediate sporoplasm. (B) Spore within a sporangium (C2) showing 3 sporoplasms; the outer sporoplasm (S1) contains one nucleus (Ns1) and numerous haplosporosomes (h); the nucleus (Ns2), mitochondria (m) and a spheroid electron-dense granular deposit (arrow) are observed in the intermediate sporoplasm (S2); the inner sporoplasm is almost only represented by its nucleus (Ns3); note the large empty space surrounding most of the surface of mature spore while winding membranes forming whorls (double arrow) connect the surface of the spore with the extraspore sporangial cytoplasm 
a partial sequence of the ITS1 region (Fig. 14). Three pairs of primers were used to obtain the sequence of a fragment of $2007 \mathrm{bp}$ of the IGS region: (1) IN4/IN2, which yielded a PCR product of $736 \mathrm{bp}$; (2) MT2B/ 18S, which yielded a product of $994 \mathrm{bp}$; and (3) MartCIGS446/MartCIGS1507, whose design was based on the $3^{\prime}$ and $5^{\prime}$ end of the sequences amplified with IN4/IN2 and MT2B/18S, respectively, and yielded a sequence of $1080 \mathrm{bp}$. The whole 18S rRNA gene sequence included $1795 \mathrm{bp}$, which was obtained using 3 pairs of primers: (1) SS1/CAS2 that yielded a 1361 bp fragment; (2) MartCIGS1809/MartC18S2639, whose design was based on the start of the $18 \mathrm{~S}$ region of Marteilia refringens (GenBank accession no. AJ250699), and the $5^{\prime}$ end of the fragment of the Marteilia sp. infecting cockles amplified with SS1/ CAS2, respectively, and yielded a 849 bp amplicon; and (3) MartC18S3564/MartC18S3755, whose design was based on the 3' sequence amplified with SS1/ CAS2 and the 5' sequence of the Marteilia sp. infecting cockles amplified with $\operatorname{Pr} 3 / \operatorname{Pr} 5$, and yielded a $210 \mathrm{bp}$ fragment. The fragment of the ITS1 region was amplified with the primers $\operatorname{Pr} 3 / \operatorname{Pr} 5$, and included $735 \mathrm{bp}$. The sequences were assembled to obtain a consensus sequence of $4433 \mathrm{bp}$ of the aetiological agent of Galician cockle marteiliosis, which was deposited in GenBank under accession number KF278722.

The 18S sequence of the Marteilia parasite infecting Galician cockles obtained in this study was $99 \%$ similar to that of $M$. cochillia from Catalonia (JN820083, JN820084; the query cover in BLAST was only $12 \%$ ) and $99 \%$ to M. refringens (AJ250699, $100 \%$ query cover in BLAST). That $18 \mathrm{~S}$ sequence showed less homology with other Paramyxida, such as Paramyxa sp. from the amphipod Echinogammarus marinus (82\%) or Marteilioides chungmuensis (78-80\%) from Crassostrea ariakensis, C. gigas and Ruditapes philippinarum, with query cover in BLAST of $47 \%$ and $98 \%$, respectively. ITS1 sequences obtained from the Marteilia parasite infecting Galician cockles also showed a 99 to $100 \%$ of homology with M. cochillia from Catalonia (JN820085-JN820090, $59 \%$ query cover in BLAST) but they were only 84 to $86 \%$ identical to $M$. refringens (64\% query cover in BLAST). Similar results were obtained with the IGS sequence of the Marteilia parasite infecting Galician cockles, which was $99 \%$ similar to the IGS sequence of $M$. cochillia from Catalonia (GenBank accession nos. JN820091 and JN820092, $15 \%$ query cover) and $85 \%$ similar to $M$. refringens (AJ604561, 65\% query cover). An insertion of 108 nucleotides was detected in the IGS region of the Marteilia parasite infecting
Galician cockles with regard to $M$. refringens, in position 529-637 of the consensus sequence KF278722. The molecular characterisation of $M$. cochillia from Catalonia did not cover this region, thus a comparative analysis between the Marteilia parasite infecting cockles from Galicia and M. cochillia from Catalonia could not be performed.

\section{Phylogenetic analyses}

The taxonomic affiliation of the Marteilia parasite infecting Galician cockles was determined by phylogenetic analyses of IGS and ITS1 regions. The IGS and ITS trees constructed with NJ (Figs. 15 \& 16) and MP (data not shown) revealed the same topology and supported that the Marteilia parasite from Galician cockles is the same species as M. cochillia from Catalonian cockles. Thus, the IGS tree constructed with a total of 269 sites showed 2 clades, containing a branch with the sequences of the Marteilia parasite infecting cockles from Galicia and with $M$. cochillia infecting cockles from Catalonia, with high bootstrap values $(100 \%)$, and another branch with M. refringens sequences (Fig. 15). The Marteilia parasite from Galician cockles clustered in a single clade with a bootstrap value of $64 \%$, while all sequences of M. cochillia from Catalonia formed another clade with a bootstrap value of $62 \%$, except the sequence JN820092. The NJ tree for ITS1 sequences, constructed with a total of 362 sites, showed a similar topology, with 2 clades; the Marteilia parasite infecting cockles from Galicia clustered in a clade with $M$. cochillia infecting cockles from Catalonia, with a bootstrap value of $100 \%$, and another clade was formed with $M$. refringens infecting different hosts (Fig. 16). The clade with cockle parasites from Galicia and Catalonia showed 2 subclades: one formed by all sequences of the Marteilia parasite from Galicia and the sequence JN820088 of M. cochillia from Catalonia, with bootstrap values of $91 \%$, and another clade including the remaining sequences of $M$. cochillia from Catalonia with a bootstrap value of $71 \%$. The sequences of the Marteilia parasite infecting Galician cockles used in the phylogenetic analysis have been deposited in GenBank under accession numbers KF263910-KF263919 for ITS1 sequences and KF263907-KF263909 for IGS sequences.

The evolutionary divergence between the Marteilia parasite infecting Galician cockles, M. sydneyi and $M$. refringens was estimated by the pairwise distance calculation based on 232 nucleotides of the ITS1 region. The genetic distance value between the 

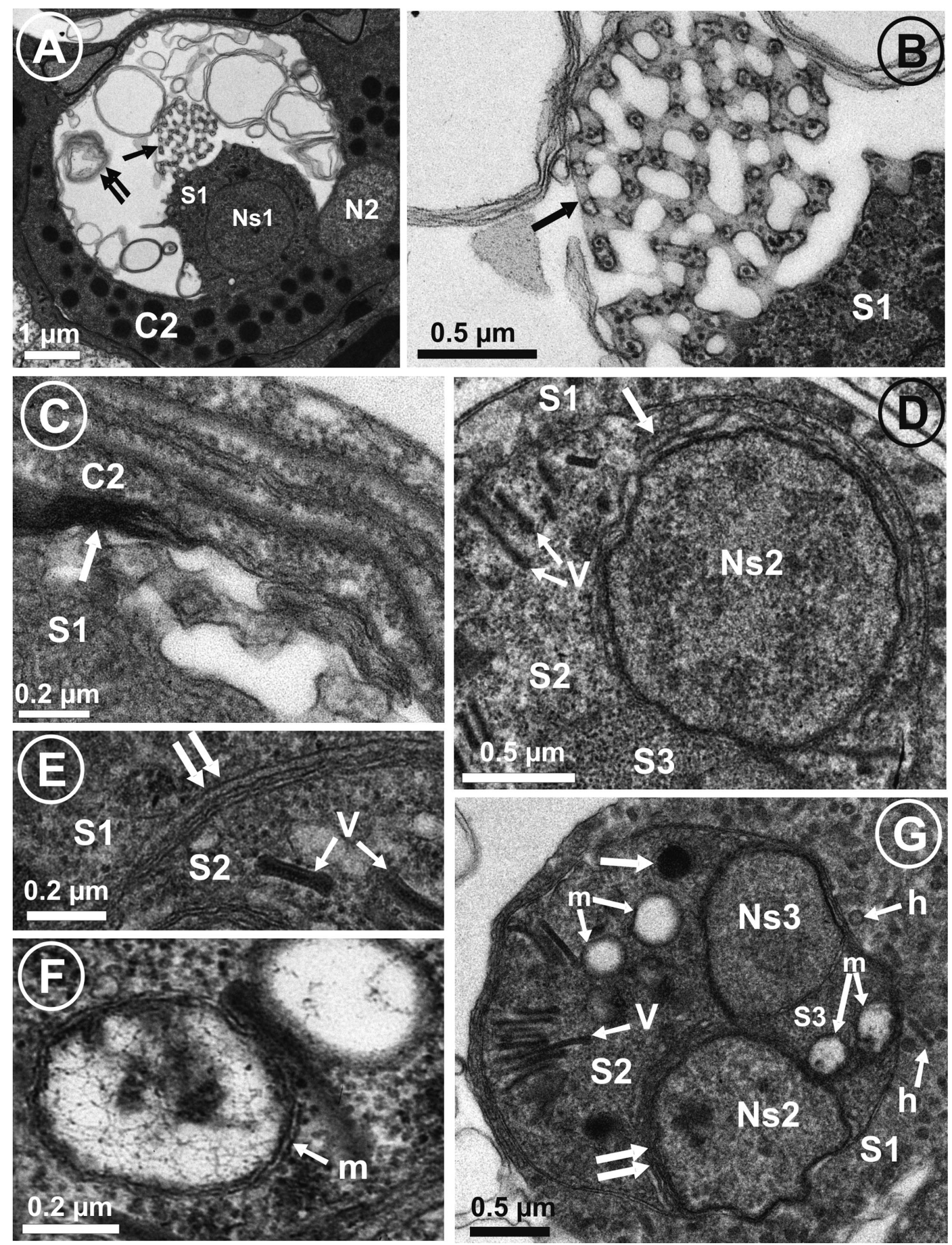
Fig. 13. Marteilia sp. infecting Cerastoderma edule. Transmission electron micrographs of the aetiological agent of marteiliosis affecting cockles in the Ría de Arousa. (A) Detail of a sporangium (C2) showing a spore with a reduced area of contact with the boundary of the vacuole where it is included, with an almost empty space surrounding most of its surface; thin anastomosing cytoplasmic projections (arrow) from the outer sporoplasm (S1) into that surrounding space can be observed; myelin whorls (double arrow) and winding membranes occur in the empty space; N2, sporangial nucleus; Ns1, nucleus of S1. (B) Detail of the thin anastomosing cytoplasmic projections (arrow) from S1 enclosing ribosomes. (C) Detail of the contact area between S1 and the sporangial (C2) cytoplasm showing various membrane layers with osmiophilic deposits (arrow). (D) Detail of a spore showing areas of the outer (S1), intermediate (S2) and inner (S3) sporoplasms; cisternae partially surrounding the nucleus of the intermediate sporoplasm (Ns2) in a double concentric arrangement (arrow) are shown; double-membrane limited flattened vermiform vesicles (V) with a knob-like enlargement at each end and electron-dense content are located in the S2. (E) Detail of a spore showing areas of S1 and S2; the boundary between both sporoplasms consists of 4 concentric membranes (double arrow); double-membrane limited flattened vermiform vesicles (V) with a knob-like enlargement at each end and electrondense content are located in S2. (F) Detail of mitochondria located in S2. (G) Detail of a spore showing areas of the outer (S1), intermediate (S2) and inner (S3) sporoplasms; haplosporosomes (h) are visible in S1; S2 shows double-membrane limited flattened vermiform vesicles (V), mitochondria (m), spheroid electron-dense granular deposits (arrow) and cisternae partially surrounding the nucleus of the intermediate sporoplasm (Ns2) in a double concentric arrangement (double arrow); 2 mitochondria (m) and the nucleus (Ns3) are shown in S3

Marteilia parasite of Galician cockles and M. refringens was 0.17, and that between the parasite of Galician cockles and M. sydneyi was 0.99 . The maximum genetic distance value was 1.09 between $M$. sydneyi and $M$. refringens.

\section{PCR assay for the detection of Marteilia cochillia}

The primer pair Mcoch-F/Mcoch-R was checked in silico for homologies with the Marteilia parasite of Galician cockles, M. refringens and M. sydneyi. The primer pair showed $100 \%$ complementarity with the ITS1 of the Marteilia parasite of cockles and low complementarity with $M$. refringens from different hosts and locations and with M. sydneyi. The analytical specificity of the pair of primers Mcoch-F/ Mcoch-R for the Marteilia parasite infecting cockles was analysed by PCR using DNA templates of Cerastoderma edule infected with M. cochillia, Mytilus galloprovincialis and Ostrea edulis infected with $M$. refringens and non-infected cockles, mussels and oysters. A PCR product of $320 \mathrm{bp}$ was observed only in samples with DNA from cockles infected with M. cochillia, whereas no amplification was observed in the remaining samples (Fig. 17). The identity of the PCR product was confirmed by sequencing.

\section{DISCUSSION}

\section{Cockle fishery collapse in the Ría de Arousa}

The periodic analysis of cockle population dynamics in Lombos do Ulla since 2002 showed a sharp decline of cockle abundance in 2012 leading to minimal levels in September 2012. A sharp decrease had also been recorded at the end of the shellfishing season in April 2006 but it was followed by quick abundance recovery. However, population dynamics were different in 2012 and, remarkably, population recovery through recruitment failed due to the disappearance of cohorts recruited in 2011 and 2012. Consistently, surveillance of adult cockle mortality in

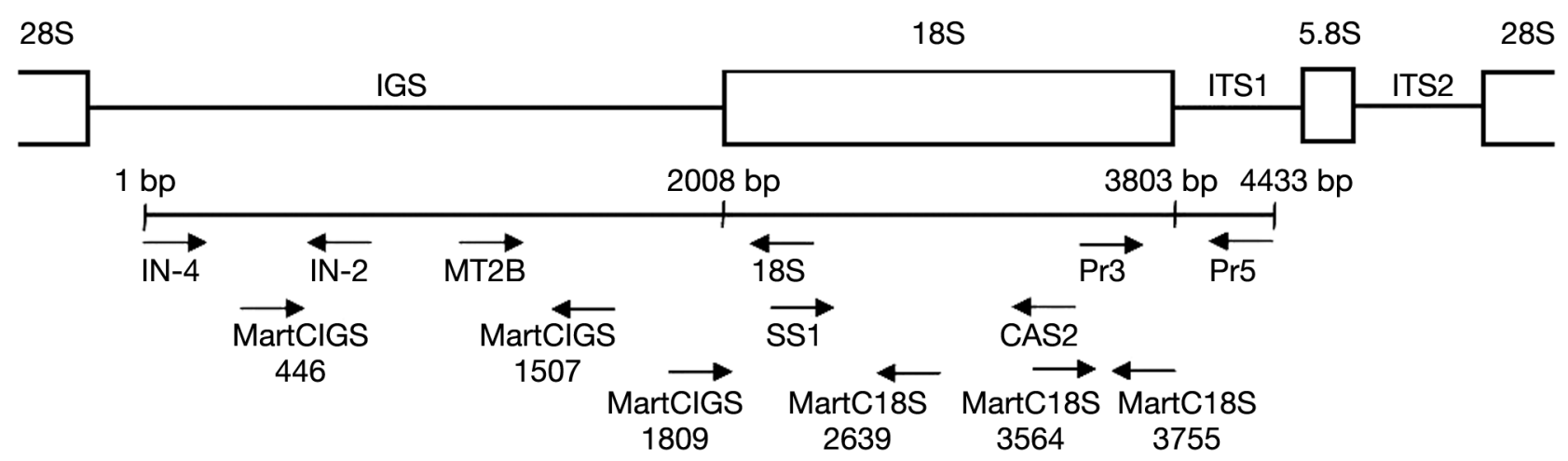

Fig. 14. Marteilia sp. Schematic representation of the nuclear ribosomal DNA of the parasite infecting Cerastoderma edule from Galicia and location of all primers used for molecular characterisation (see Table 1 for primer details) 


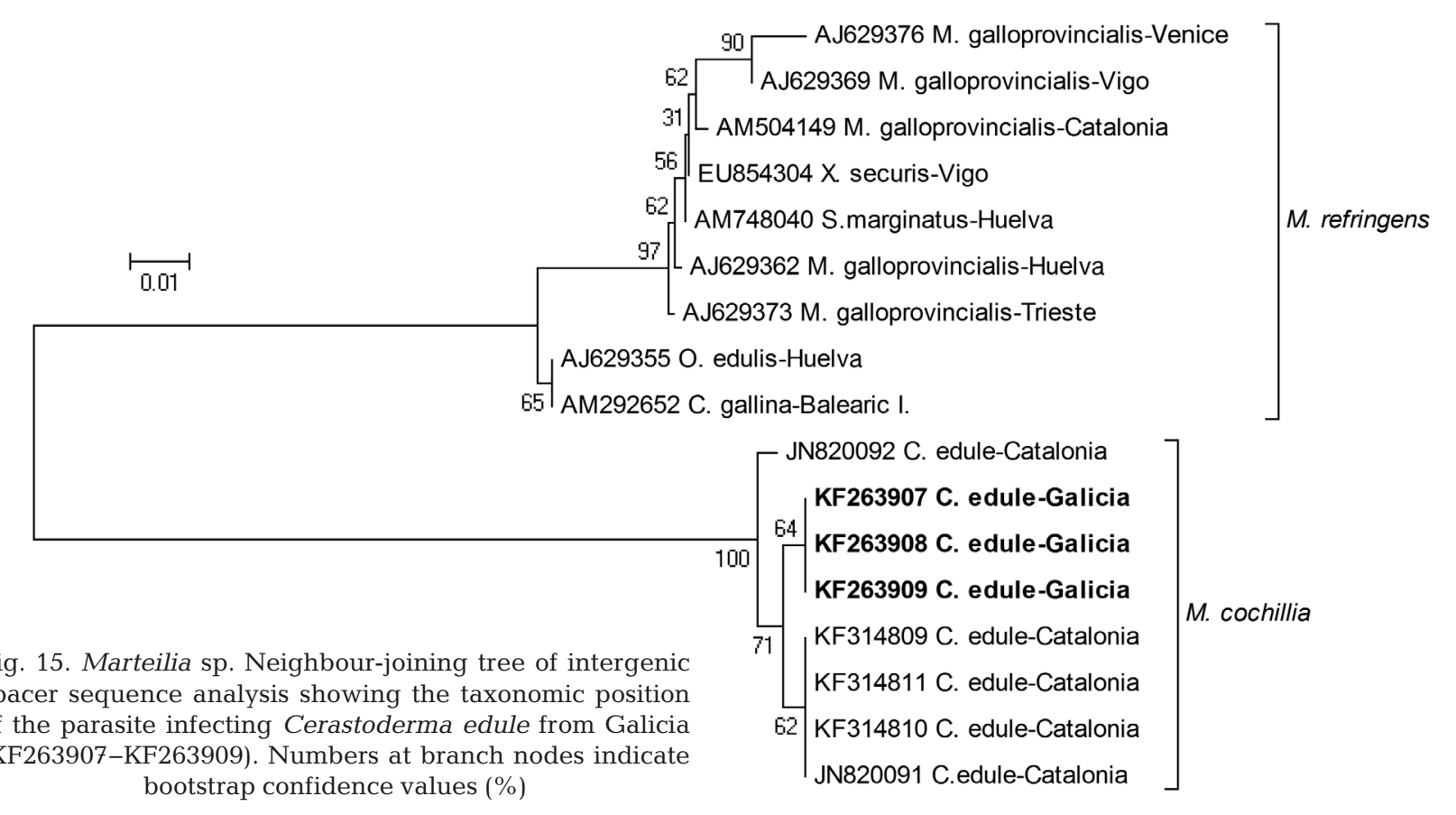

Fig. 15. Marteilia sp. Neighbour-joining tree of intergenic spacer sequence analysis showing the taxonomic position of the parasite infecting Cerastoderma edule from Galicia (KF263907-KF263909). Numbers at branch nodes indicate bootstrap confidence values (\%)

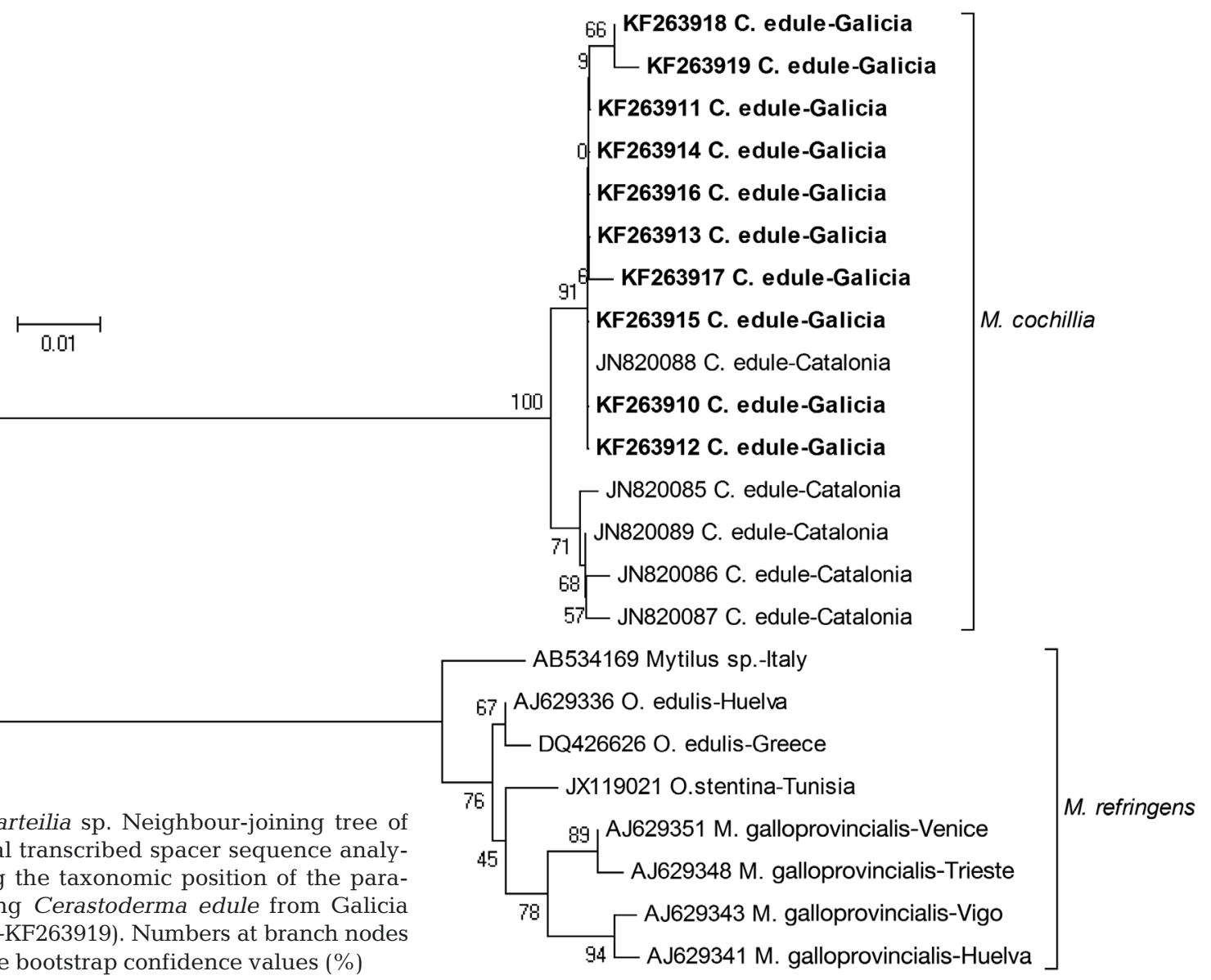

Fig. 16. Marteilia sp. Neighbour-joining tree of first internal transcribed spacer sequence analysis showing the taxonomic position of the parasite infecting Cerastoderma edule from Galicia (KF263910-KF263919). Numbers at branch nodes indicate bootstrap confidence values (\%) 


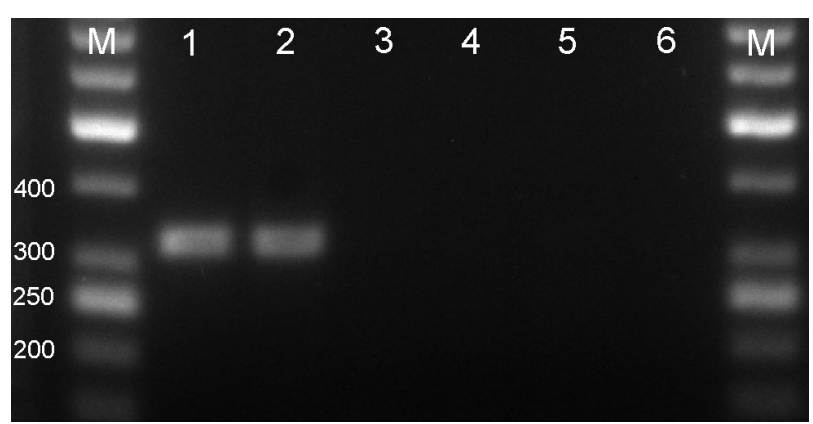

Fig. 17. Agarose gel electrophoresis after PCR assay performed to assess analytical specificity of primers Mcoch-F/ Mcoch-R. Lanes 1 and 2: Galician Cerastoderma edule infected with Marteilia cochillia; Lane 3: non-infected C. edule; Lane 4: Mytilus galloprovincialis infected with Marteilia refringens; Lane 5: Ostrea edulis infected with $M$. refringens; Lane 6: negative control; M: 50 bp molecular marker

submersed boxes showed a sharp increase in early 2012 leading to an unprecedented $100 \%$ mortality in May 2012. Mass cockle mortality had to occur in the whole Ría de Arousa because unprecedented decline of cockle catches were recorded from May 2012 leading to no catch from August to December 2012.

\section{Cause of cockle mass mortality}

Episodes of high cockle mortality in the estuarine area of Lombos do Ulla due to low salinity after heavy rain had been recorded previously, but they had usually been limited to areas in proximity to river mouths and had not affected every bed in the Ría de Arousa. Salinity records in the period 2011 to 2012 were even higher and the range was narrower than in previous years, except a few days in January 2011; thus salinity cannot be blamed for the cockle mass mortality in 2012. Furthermore, there were no records or claims of abnormal high mortality of other mollusc species highly susceptible to low salinity, such as the pullet carpet-shell clam Venerupis corrugata in 2012 in Lombos do Ulla. Temperature should be also discounted because no atypical value was recorded in the period 2011 to 2012 compared to the period 2009 to 2010. Considering the potentially lethal pathological conditions, the prevalence values of disseminated neoplasia and LFHHI (Villalba et al. 2001) in 2012 were among the lowest in the period 2007 to 2012 . However, the prevalence of marteiliosis in adult cockles from Lombos do Ulla increased sharply from its first detection in association with the mortality rate, up to $100 \%$ of both prevalence and mortality rate. The association between sharp increments of marteiliosis and mortality up to $100 \%$ was also observed in the cohorts recruited in 2011 and 2012, which indicated that juvenile and adult cockles were highly susceptible to marteiliosis. This infection was also detected in every sampled cockle bed of the Ría de Arousa, except in the one nearest to the ocean, in May to July 2012, when the cockle catches in the Ría de Arousa had sharply declined; shortly thereafter, the cockle catch in the whole Ría de Arousa became negligible, which was unprecedented. However, marteiliosis was not detected in the sampled beds located in other rías of Galicia, where no abnormal decline of cockle abundance was reported in 2012.

Our results support that marteiliosis was the most likely cause of the cockle fishery collapse in the Ría de Arousa. The responsibility of marteiliosis for dramatic losses of other commercial mollusc species is well known: Marteilia refringens and $M$. sydneyi, respectively, have caused mass mortalities of the European flat oyster Ostrea edulis in various European countries (Grizel et al. 1974, Massó 1978, Alderman 1979, van Banning 1979) and the Sydney rock oyster Saccostrea glomerata in Australia (Wolf 1979, Green et al. 2008, Dang et al. 2013). The aetiological agent of marteiliosis in Galician cockles proliferated through host digestive diverticula, where sporulation took place. Similarly, sporulation takes place in host digestive diverticula in the case of $M$. refringens (Grizel et al. 1974, Villalba et al. 1993a), M. sydneyi (Perkins \& Wolf 1976, Kleeman \& Adlard 2000, Kleeman et al. 2002), M. christenseni (Comps 1983), M. cochillia (Carrasco et al. 2011, 2013) and Marteilia sp. infecting cockles in France (Comps et al. 1975). Heavy marteiliosis of cockles involved the occurrence of parasites occupying large areas of the epithelium of every digestive tubule, which would hinder food absorption, as was demonstrated for M. refringens infecting M. galloprovincialis (PérezCamacho et al. 1997), leading to starvation and eventually death. The pathogenicity of marteiliosis and the susceptibility of both adult and juvenile cockles are serious obstacles for restoration of the cockle fishery in the Ría de Arousa. A thorough epidemiological study of cockle marteiliosis is necessary to design recovery strategies, and maximal caution to avoid spreading this pathogen is advisable.

\section{Characterisation of the aetiological agent of marteiliosis in Galician cockles}

The sporulation process observed in the Galician cockle parasite involving the development within a primary cell of various sporangia which produce 
spores made of cells enclosed inside each other links this parasite with the Paramyxea (Desportes 1984, Desportes \& Perkins 1990), later classified as order Paramyxida (CavalierSmith \& Chao 2003). Considering morphological characters with taxonomic value within this order, which includes the genera Paramyxa, Marteilia, Paramarteilia and Marteilioides, the occurrence of sporangia enclosing various tricellular spores corresponds to the genus Marteilia (Desportes 1984, reviewed by Feist et al. 2009). Light microscopy examination showed that the agent of marteiliosis of Galician cockles had sporangia enclosing 6 spores, and each spore contained up to 3 nuclei; TEM examination showed that each mature spore consisted of 3 sporoplasms. Therefore, morphological characters support the inclusion of this cockle parasite in the genus Marteilia. Morphological differences between this parasite of Galician cockles and other described Martelia species ( $M$. refringens, $M$. sydneyi, $M$. christenseni and $M$. cochillia) were found, as shown in Table 4. However, there was concordance with the sparse description of the Marteilia sp. infecting cockles in France (Comps et al. 1975) (Table 4). Another coincidence is the occurrence of a microsporidian hyperparasite both in the Marteilia sp. parasitising cockles in France (Comps et al. 1975) and in the parasite infecting Galician cockles, although hyperparasitisation with microsporidians has also been observed in $M$. refringens infecting Ostrea edulis (Comps et al. 1979) and M. galloprovincialis (Villalba et al. 1993a). Not many details were provided by López \& Darriba (2006) on morphological characters of Marteilia sp. infecting razor clams Solen marginatus; the authors reported that up to 6 spores per sporangium were seen with TEM, but 8 spores per sporangium were observed in imprints examined with

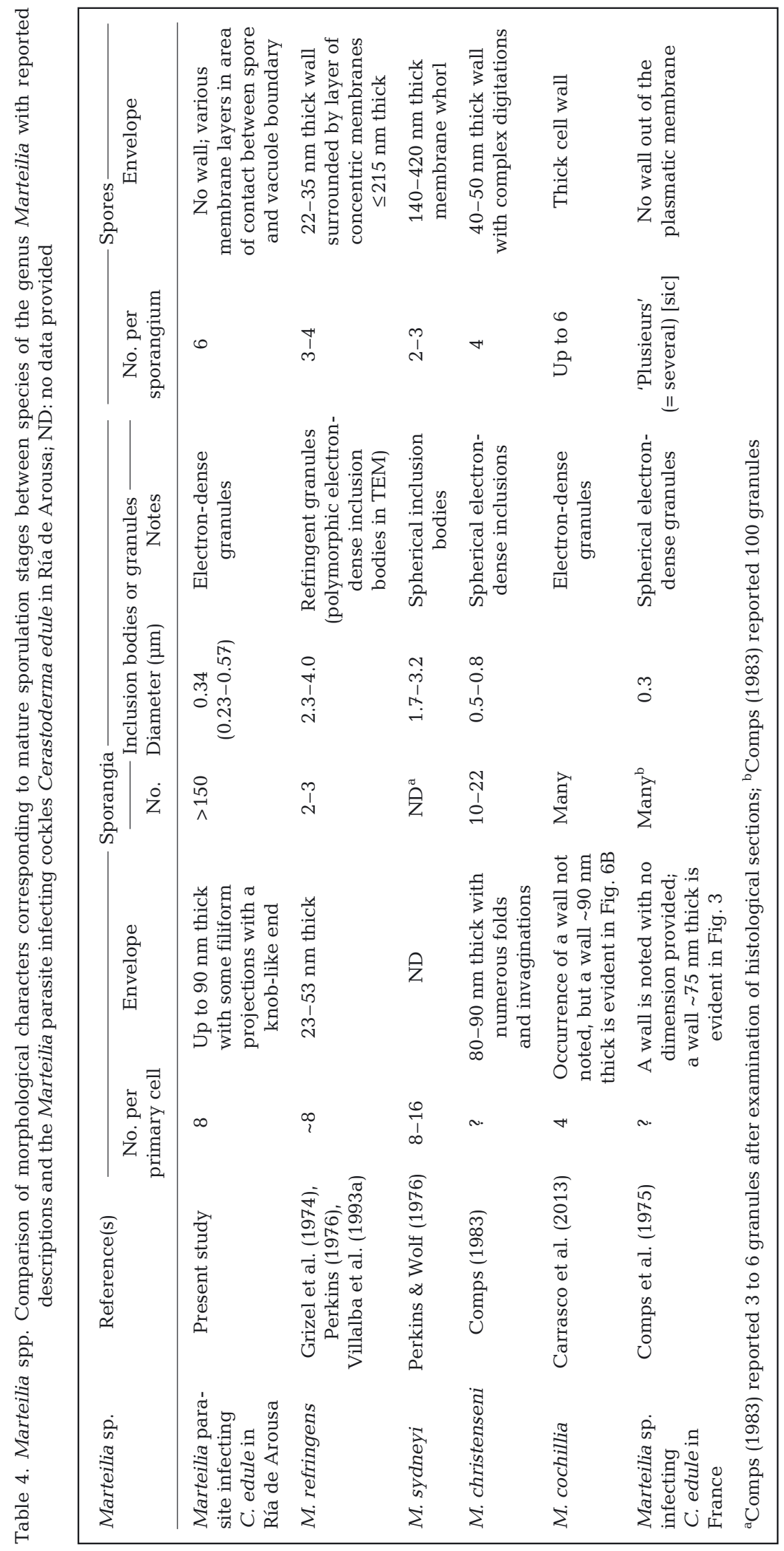


light microscopy (C. López \& S. Darriba pers. obs.), which distinguishes this parasite from that infecting Galician cockles; furthermore, the authors observed electron-dense granules in the cytoplasm of secondary cells with a mean size of $0.58 \mu \mathrm{m}$ (López \& Darriba 2006), larger than those of the Galician cockle parasite. The comparison of the Marteilia parasite of the Galician cockles with the description of morphological characters of $M$. cochillia infecting cockles from Catalonia (Carrasco et al. 2013) reveals similarities and disagreements; the number of sporangia per primary cell is lower in the parasite from Catalonian cockles, but Carrasco et al. (2013) stated that number (4) based on TEM observations, which is much less accurate than estimation based on examining serial histological sections of infected cockles, due to the size of primary cells and sporangia. In fact, the images of histological sections included in the paper on the Marteilia sp. parasitising Catalonian cockles (Carrasco et al. 2011) markedly resemble those of the parasite of the Galician cockles. The number of spores per sporangium is 6 in both cases, but spores are contained within 'amorphous proteic masses' (2 spores per proteic mass) in $M$. cochillia infecting Catalonian cockles, whereas such spore packaging in pairs was not observed in the Marteilia parasite of Galician cockles. The thick spore wall referred to in the description of $M$. cochillia was not observed in the Galician parasite. Numerous electron-dense granules occur in the extraspore cytoplasm of the sporangia in both parasites, but a wider electron-lucent halo between the membrane and the electron-dense core was obvious in the images of the granules of $M$. cochillia infecting Catalonian cockles. M. lengehi (Comps 1976) and $M$. maurini (Comps et al. 1981) are not included in the comparison, the former because of the lack of morphological description and the latter because there were no morphological characters distinguishing it from M. refringens (Villalba et al. 1993a, Longshaw et al. 2001). Feist et al. (2009) postulated that Marteilioides chungmuensis, a parasite whose sporulation takes place in the ovocytes of the molluscan host, should be included in the genus Marteilia because of its tricellular spore; the parasite of the Galician cockles was different from $M$. chungmuensis because the latter has 1 spore per sporangium and the inner sporoplasm can divide in 2 cells (Comps et al. 1986). The thin anastomosing cytoplasmic projections from the outer sporoplasm observed in the parasite of the Galician cockles had not been described in other Marteilia parasites, but their taxonomic value is uncertain since they could be a result of spore retraction caused by fixation.
Molecular characterisation of the aetiological agent of marteiliosis in Galician cockles showed $99 \%$ homology with Marteilia refringens in the 18S sequence and $82 \%$ or lower with other Paramyxida species, which supports the inclusion of the cockle parasite in the genus Marteilia. However, the sequences corresponding to ITS1 and IGS of the Galician cockle parasite showed $84 \%$ and $85 \%$ homology, respectively, with $M$. refringens. Regarding the deposited ITS1 sequence of $M$. sydneyi, the distance between this species and the Galician cockle parasite is even longer than that between the cockle parasite and $M$. refringens; therefore, molecular results together with morphological differences mentioned above support considering the Galician cockle parasite as a different species from $M$. refringens and $M$. sydneyi. Unfortunately, no DNA sequence of the species $M$. christenseni is available for molecular comparison with the Galician cockle parasite, but morphological differences mentioned above support considering both as different species. The comparison of the consensus sequence of the Galician cockle parasite including the IGS, ITS1 and 18S regions with the fragment sequences of those regions of the $M$. cochillia infecting cockles from Catalonia showed 99 to $100 \%$ homology. Phylogenetic analyses of ITS1 and IGS sequences allocated M. refringens into a different clade from that including the cockle parasites from Galicia and Catalonia, which is consistent with the analysis of IGS sequences performed by Carrasco et al. (2013), in which the sequences of $M$. refringens and those of M. cochillia were allocated into different clades. The molecular similarity supports considering the parasite of Galician cockles as M. cochillia, while the morphological differences mentioned above should be further analysed to assess whether they correspond to intraspecific variability or inaccurate examination. The Marteilia sp. parasite reported from cockles in France (Comps et al. 1975) likely corresponds to the same species, but the sparse morphological description and the lack of molecular information preclude a definitive identification. M. cochillia seems to have high host specificity for Cerastoderma edule because the parasite has been recorded neither in samples of clams Ruditapes philippinarum and Venerupis corrugata taken from Lombos do Ulla nor in mussels Mytilus galloprovincialis taken from rafts close to that area while marteiliosis was heavily affecting cockles; some of those mussels were affected by $M$. refringens, which was diagnosed both with histology and PCR (data not shown). 
The sudden unprecedented outbreak of Marteilia cochillia in the Ría de Arousa far from any other known affected area suggests an unintentional recent introduction of the parasite into this area. A hypothetical vehicle could have been cockles imported into the Ría de Arousa or other invertebrates that could harbour the parasite. Imports of molluscs for farming purposes are frequent in this area. Extreme caution is needed to avoid spreading this disease, bearing in mind that transferring cockles from the Ría de Arousa to depuration plants located in other Galician rías is frequent and that transplanting cockles to other places is not rare.

\section{PCR assay for detection of Marteilia cochillia}

The PCR assays performed with the primer pair Mcoch-F/Mcoch-R allowed discrimination between $M$. cochillia and $M$. refringens. The lack of materials infected with $M$. sydneyi or $M$. christenseni avoided the inclusion of these species in the tests on analytical specificity, although in silico test indicates lack of amplification for M. sydneyi. Carrasco et al. (2012) designed an RFLP assay allowing discrimination between the Marteilia sp. infecting cockles from Catalonia and $M$. refringens. This RFLP assay is linked to the nested PCR designed by López-Flores et al. (2004) to diagnose $M$. refringens. The Marteilia parasite of Galician cockles yielded the same restriction pattern as $M$. Cochillia infecting cockles from Catalonia with this RFLP assay (data not shown). The conventional PCR designed in this study allows quicker and simpler diagnosis than the RFLP procedure and is particularly useful in areas where $M$. refringens and $M$. cochillia co-occur.

Acknowledgements. Comments of anonymous reviewers helped to improve the manuscript. We thank B. González Castro (Universidad de Vigo) for advice on mortality rate calculations. C. E. Álvarez Belin, P. Carreira Vázquez, C. Darriba Santiago, L. García Alves, G. Martínez Verde and M. Miranda Bamio took part in sampling campaigns and processing. J. and M. Leiro Cores and members of the crew of the boat 'Begoña Segunda' helped in sampling. M. L. Fernández Cañamero and L. Gómez Gesteira (Centro Tecnológico del Mar - Fundación CETMAR) managed administrative issues of the programme on shellfish population dynamics in Lombos do Ulla. M. Nédélec provided flat oysters from Brittany. B. Bustos, E. Penas Pampín, M. I. Meléndez Ramos, R. Alves Garaña, D. Vilar Fernández, S. Bastos, B. Fariña, J. M. Marchena and D. Amo provided technical assistance. Sample processing and examination with transmission electron microscopy were performed in the Servicio de Microscopía Electrónica of CACTI (Universidad de Vigo) with technical assistance by I. Pazos. This study was partly funded by the Consellería do Medio Rural e do Mar da Xunta de Galicia, through the project PGIDIT-CIMA 12/03.

\section{LITERATURE CITED}

Adl SM, Simpson AGB, Farmer MA, Andersen RA and others (2005) The new higher level classification of eukaryotes with emphasis on the taxonomy of protists. J Eukaryot Microbiol 52:399-451

Alderman DJ (1979) Epizootiology of Marteilia refringens in Europe. Mar Fish Rev 41:67-69

Aranguren R, Poisa-Beiro L, Villalba A, Figueras A (2011) Maretiliosis en moluscos. In: Figueras A, Novoa B (eds) Enfermedades de moluscos bivalvos de interés en acuicultura. Fundación Observatorio Español de Acuicultura, Madrid, p 245-282

> Audemard C, Le Roux F, Barnaud A, Collins C and others (2002) Needle in a haystack: involvement of the copepod Paracartia grani in the life cycle of the oyster pathogen Marteilia refringens. Parasitology 124:315-323

> Berthe FCJ, Le Roux F, Peyretaillade E, Peyret P, Rodriguez D, Gouy M, Vivares CP (2000) Phylogenetic analysis of the small subunit ribosomal RNA of Marteilia refringens validates the existence of Phylum Paramyxea (Desportes and Perkins, 1990). J Eukaryot Microbiol 47:288-293

Berthe FCJ, Le Roux F, Adlard R, Figueras A (2004) Marteiliosis in molluscs: a review. Aquat Living Resour 17: 433-448

> Carballal MJ, Iglesias D, Santamarina J, Ferro-Soto B, Villalba A (2001) Parasites and pathologic conditions of the cockle Cerastoderma edule populations of the coast of Galicia (NW Spain). J Invertebr Pathol 78:87-97

Carrasco N, Roque A, Andree KB, Rodgers C, Lacuesta B, Furones MD (2011) A Marteilia parasite and digestive epithelial virosis lesions observed during a common edible cockle Cerastoderma edule mortality event in the Spanish Mediterranean coast. Aquaculture 321:197-202

Carrasco N, Andree KB, Lacuesta B, Roque A, Rodgers C, Furones MD (2012) Molecular characterization of the Marteilia parasite infecting the common edible cockle Cerastoderma edule in the Spanish Mediterranean coast. A new Marteilia species affecting bivalves in Europe? Aquaculture 324-325:20-26

Carrasco N, Hine PM, Durfort M, Andree KB and others (2013) Marteilia cochillia sp. nov., a new Marteilia species affecting the edible cockle Cerastoderma edule in European Waters. Aquaculture 412-413:223-230

Cavalier-Smith T, Chao EE (2003) Phylogeny and classification of phylum Cercozoan (Protozoa). Protist 154:341-358

Comps M (1976) Marteilia lengehi n. sp., parasite de l'huître Crassostrea cucullata Born. Rev Trav Inst Pêch Marit 40: 347-349

Comps M (1983) Etude morphologique de Marteilia christenseni sp. n. parasite du lavignon Scrobicularia piperata P. (mollusque pelecypode). Rev Trav Inst Pêch Marit 47: 99-104

Comps M, Grizel H, Tigé G, Duthoit JL (1975) Parasites nouveaux de la glande digestive des mollusques marins Mytilus edulis L. et Cardium edule. C R Acad Sci 281: 179-181

Comps M, Pichot Y, Deltreil JP (1979) Mise en evidence d'une microsporidie parasite de Marteilia refringens agent de la maladie de la glande digestive de Ostrea edulis L. Rev Trav Inst Pêch Marit 43:409-412

Comps M, Pichot Y, Papagianni P (1981) Research on Marteilia maurini n.sp. parasite of the mussel Mytilus galloprovincialis Lmk. Rev Trav Inst Pêch Marit 45:211-214 
Comps M, Park MS, Desportes N (1986) Etude ultrastructurale de Marteilioides chungmuensis n.g., n.sp. parasite des ovocytes de l'huitre Crassostrea gigas Th. Protistologica 22:279-285

Council of the European Union (2006) Council Directive 2006/88/EC of 24 October 2006 on animal health requirements for aquaculture animals and products thereof, and on the prevention and control of certain diseases in aquatic animals. Off J Eur Union L328: 14-56

Dang C, Cribb TH, Cutmore SC, Chan J, Hénault O, Barnes AC (2013) Parasites of QX-resistant and wild-type Sydney rock oysters (Saccostrea glomerata) in Moreton Bay, SE Queensland, Australia: diversity and host response. J Invertebr Pathol 112:273-277

Desportes I (1984) The Paramyxea Levine 1979: an original example of evolution towards multicellularity. Orig Life 13:343-352

Desportes I, Perkins FO (1990) Phylum Paramyxea. In: Margulis L, Corliss JO, Melkonian M, Chapman DI (eds) Handbook of Protoctista. Jones and Bartlett Publishing, Boston, MA, p 30-35

> Feist SW, Hine PM, Bateman KS, Stentiford GD, Longshaw M (2009) Paramarteilia canceri sp. n. (Cercozoa) in the European edible crab (Cancer pagurus) with a proposal for the revision of the order Paramyxida Chatton, 1911. Folia Parasitol 56:73-85

> Green TJ, Jones BJ, Adlard RD, Barnes AC (2008) Parasites, pathological conditions and mortality in QX resistant and wild caught Sydney rock oysters Saccostrea glomerata. Aquaculture 280:35-38

Grizel H, Comps M, Bonami JR, Cousserans F, Duthoit J L, Le Pennec MA (1974) Recherche sur l'agent de la maladie de la glande digestive de Ostrea edulis Linné. Sci Pêch 240:7-29

> Itoh N, Oda T, Yoshinaga T, Ogawa K, Wakabayashi $\mathrm{H}$ (2002) Identification and development of paramyxean ovarian parasite in the Pacific oyster Crassostrea gigas. Fish Pathol 37:23-28

King M (2007) Fisheries biology, assessment and management, 2nd edn. Blackwell Publishing, Oxford

> Kleeman SN, Adlard RD (2000) Molecular detection of Marteilia sydneyi, pathogen of Sydney rock oysters. Dis Aquat Org 40:137-146

- Kleeman SN, Adlard RD, Lester RJG (2002) Detection of the initial infective stages of the protozoan parasite Marteilia sydneyi in Saccostrea glomerata and their development through to sporogenesis. Int J Parasitol 32:767-784

Krebs CJ (1998) Ecological methodology, 2nd edn. Addison Wesley Longman Publishers, Menlo Park, CA

> Le Roux F, Lorenzo G, Peyret P, Audemard C and others (2001) Molecular evidence for the existence of two species of Marteilia in Europe. J Eukaryot Microbiol 48: $449-454$

> Longshaw M, Feist SW, Matthews A, Figueras A (2001) Ultrastructural characterisation of Marteilia species (Paramyxea) from Ostrea edulis, Mytilus edulis and Mytilus galloprovincialis in Europe. Dis Aquat Org 44:137-142

López C, Darriba S (2006) Presence of Marteilia sp. (Paramyxea) in the razor clam Solen marginatus (Pennántt, 1777) in Galicia (NW Spain). J Invertebr Pathol 92: 109-111

López-Flores I, de la Herrán R, Garrido-Ramos MA, Navas JI, Ruiz-Rejón C, Ruiz-Rejón M (2004) The molecular diagnosis of Marteilia refringens and differentiation between Marteilia strains infecting oysters and mussels based on the rDNA IGS sequence. Parasitology 129: 411-419

Massó J (1978) La enfermedad de la glándula digestiva de la ostra ('Ostrea edulis L.') en las Rías Bajas. Bol Inst Esp Oceanogr 251:125-140

Parada JM, Molares J (2009) Unha ferramenta para a avaliación de recursos marisqueiros. ARouSA. Consellería do Mar, Xunta de Galicia, Santiago de Compostela

Parada JM, Molares J (2013) Artisanal exploitation of natural clam beds: organization and management tools. In: da Costa Gonzalez F (ed) Clam fisheries and aquaculture. Nova Science Publishers, New York, NY, p 273-289

Parada JM, Molares J, Sánchez-Mata A, Martínez G, Darriba C, Mariño J (2006) Plan de actuación para la recuperación del banco 'Lombos do Ulla': campañas marisqueras desde 2002 a 2005. Rev Galega Recurs Mar 1: $1-37$

Parada JM, Molares J, Otero X (2012) Multispecies mortality patterns of commercial bivalves in relation to estuarine salinity fluctuation. Estuaries Coasts 35:132-142

> Pascual S, Villalba A, Abollo E, Garci M and others (2010) The mussel Xenostrobus securis: a well-established alien invader in the Ria de Vigo (Spain, NE Atlantic). Biol Invasions 12:2091-2103

Pérez-Camacho A, Villalba A, Beiras R, Labarta U (1997) Absorption efficiency and condition of cultured mussels (Mytilus edulis galloprovincialis Linnaeus) of Galicia (NW Spain) infected by parasites Marteilia refringens Grizel et al. and Mytilicola intestinalis Steuer. J Shellfish Res 16:77-82

Perkins FO (1976) Ultrastructure of sporulation in the European flat oyster pathogen, Marteilia refringens - taxonomic implications. J Protozool 23:64-74

Perkins FO (1979) Cell structure of shellfish pathogens and hyperparasites in the genera Minchinia, Urosporidium, Haplosporidium and Marteilia — taxonomic implications. Mar Fish Rev 41:25-37

Perkins FO (1988) Structure of protistan parasites found in bivalve mollusks. Am Fish Soc Spec Publ 18:93-111

> Perkins FO, Wolf PH (1976) Fine structure of Marteilia sydneyi sp. n. - haplosporidian pathogen of Australian oysters. J Parasitol 62:528-538

Rozen S, Skaletsky HJ (2000) Primer3 on the WWW for general users and for biologist programmers. In: Krawetz S, Misener S (eds) Bioinformatics methods and protocols: methods in molecular biology. Humana Press, Totowa, NJ, p 365-386

Tamura K, Dudley J, Nei M, Kumar S (2007) MEGA4: Molecular Evolutionary Genetics Analysis (MEGA) software version 4.0. Mol Biol Evol 24:1596-1599

Thompson JD, Higgins DG, Gibson TJ (1994) CLUSTAL W: improving the sensitivity of progressive multiple sequence alignment through sequence weighting, positions-specific gap penalties and weight matrix choice. Nucleic Acids Res 22:4673-4680

van Banning P (1979) Haplosporidian diseases of imported oysters, Ostrea edulis, on Dutch estuaries. Mar Fish Rev 41:8-18

Villalba A, Mourelle SG, López MC, Carballal MJ, Azevedo C (1993a) Marteiliasis affecting cultured mussels Mytilus galloprovincialis of Galicia (NW Spain). I. Etiology, phases of the infection, and temporal and spatial variability in prevalence. Dis Aquat Org 16:61-72

Villalba A, Mourelle SG, Carballal MJ, López MC (1993b) 
Effects of infection by the protistan parasite Marteilia refringens on the reproduction of cultured mussels Mytilus galloprovincialis in Galicia (NW Spain). Dis Aquat Org 17:205-213

- Villalba A, Mourelle SG, Carballal MJ, López C (1997) Symbionts and diseases of farmed mussels Mytilus galloprovincialis throughout the culture process in the Rías of Galicia (NW Spain). Dis Aquat Org 31:127-139

Villalba A, Carballal MJ, López C (2001) Disseminated neoplasia and large foci indicating heavy haemocytic infil- tration in cockles Cerastoderma edule from Galicia (NW Spain). Dis Aquat Org 46:213-216

Wolf PH (1979) Life cycle and ecology of Marteilia sydneyi in the Australian oyster, Crassostrea commercialis. Mar Fish Rev 41:70-73

World Organisation for Animal Health (2013) Infection with Marteilia refringens. In: OIE (ed) Manual of diagnostic tests for aquatic animals. OIE, Paris. Available at www.oie.int/en/international-standard-setting/aquaticmanual/access-online/ (accessed 8 January 2014)

Submitted: July 24, 2013; Accepted: January 15, 2014 Proofs received from author(s): March 25, 2014
Editorial responsibility: Stephen Feist, Weymouth, UK 